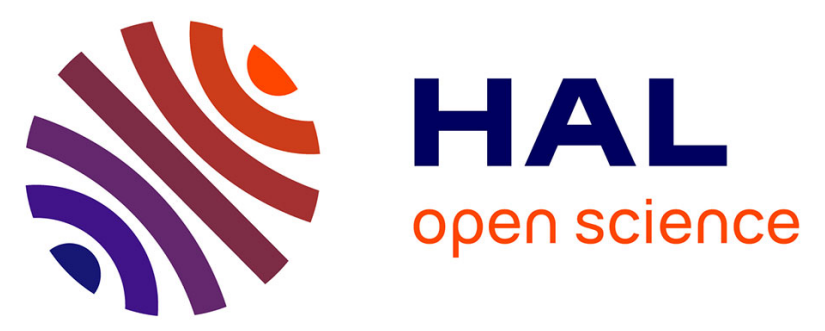

\title{
80's population-specific compositions of two related anadromous shad species during the oceanic phase determined by microchemistry of archived otoliths
}

\author{
David José Nachón, Gilles Bareille, Hilaire Drouineau, Hélène Tabouret, \\ Catherine Taverny, Catherine Boisneau, Sylvain Bérail, Christophe Pécheyran, \\ Fanny Claverie, Françoise Daverat
}

\section{To cite this version:}

David José Nachón, Gilles Bareille, Hilaire Drouineau, Hélène Tabouret, Catherine Taverny, et al.. 80's population-specific compositions of two related anadromous shad species during the oceanic phase determined by microchemistry of archived otoliths. Canadian Journal of Fisheries and Aquatic Sciences, 2020, 77 (1), pp.164-176. 10.1139/cjfas-2018-0444 . hal-02175519

\author{
HAL Id: hal-02175519 \\ https://hal.science/hal-02175519
}

Submitted on 10 Nov 2020

HAL is a multi-disciplinary open access archive for the deposit and dissemination of scientific research documents, whether they are published or not. The documents may come from teaching and research institutions in France or abroad, or from public or private research centers.
L'archive ouverte pluridisciplinaire HAL, est destinée au dépôt et à la diffusion de documents scientifiques de niveau recherche, publiés ou non, émanant des établissements d'enseignement et de recherche français ou étrangers, des laboratoires publics ou privés. 


\section{Canadian Journal of Fisheries and Aquatic Sciences}

\section{0's population-specific compositions of two related anadromous shad species during the oceanic phase determined by microchemistry of archived otoliths}

\begin{tabular}{|c|c|}
\hline Journal: & Canadian Journal of Fisheries and Aquatic Sciences \\
\hline Manuscript ID & cjfas-2018-0444.R1 \\
\hline Manuscript Type: & Article \\
\hline $\begin{array}{l}\text { Date Submitted by the } \\
\text { Author: }\end{array}$ & 05-Mar-2019 \\
\hline Complete List of Authors: & $\begin{array}{l}\text { Nachón, David; IRSTEA EABX, Aquatic Ecosystems and Global Changes } \\
\text { research unit, } 50 \text { avenue de Verdun } 33612 \text {; Estación de Hidrobioloxía } \\
\text { 'Encoro do Con', Universidade de Santiago de Compostela, Castroagudín, } \\
\text { s/n } 36617 \\
\text { Bareille, Gilles; CNRS/ Univ Pau \& Pays Adour/ e2s UPPA, Institut des } \\
\text { Sciences Analytiques et de Physicochimie pour I'Environnement et les } \\
\text { Materiaux - MIRA*, UMR 5254, 64000, } \\
\text { Drouineau, Hilaire; IRSTEA EABX, Aquatic Ecosystems and Global } \\
\text { Changes research unit, } 50 \text { avenue de Verdun 33612 } \\
\text { Tabouret, Hélène; CNRS/ Univ Pau \& Pays Adour/ e2s UPPA, Institut des } \\
\text { Sciences Analytiques et de Physicochimie pour l'Environnement et les } \\
\text { Materiaux - MIRA*, UMR 5254, 64000, } \\
\text { Taverny, Catherine; F.D.A.A.P.P.M.A. 33, 10 ZA du Lapin - 33750 } \\
\text { Boisneau, Catherine; UMR CNRS CITERES 7324, Université de Tours, } 33 \\
\text { Allée F de Lesseps, 37200 } \\
\text { Berail, Sylvain; CNRS/ Univ Pau \& Pays Adour/ e2s UPPA, Institut des } \\
\text { Sciences Analytiques et de Physicochimie pour I'Environnement et les } \\
\text { Materiaux - MIRA*, UMR 5254, 64000, } \\
\text { Pécheyran, Christophe; CNRS/ Univ Pau \& Pays Adour/ e2s UPPA, } \\
\text { Institut des Sciences Analytiques et de Physicochimie pour } \\
\text { I'Environnement et les Materiaux - MIRA*, UMR 5254, 64000, } \\
\text { Claverie, Fanny; CNRS/ Univ Pau \& Pays Adour/ e2s UPPA, Institut des } \\
\text { Sciences Analytiques et de Physicochimie pour I'Environnement et les } \\
\text { Materiaux - MIRA*, UMR 5254,64000, } \\
\text { Daverat, Françoise; IRSTEA EABX, Aquatic Ecosystems and Global } \\
\text { Changes research unit, } 50 \text { avenue de Verdun } 33612\end{array}$ \\
\hline Keyword: & $\begin{array}{l}\text { MARINE < Environment/Habitat, BIOCHEMISTRY < General, ECOLOGY < } \\
\text { General, DISPERSAL < General, DIADROMOUS SPECIES < Organisms }\end{array}$ \\
\hline $\begin{array}{r}\text { Is the invited manuscript for } \\
\text { consideration in a Special } \\
\text { Issue? : }\end{array}$ & Not applicable (regular submission) \\
\hline
\end{tabular}




\section{SCHOLARONE ${ }^{m}$ Manuscripts}




\section{0's population-specific compositions of two related anadromous shad species during the oceanic phase determined by microchemistry of archived otoliths}

David José Nachón ${ }^{1}$, Gilles Bareille, Hilaire Drouineau, Hélène Tabouret, Catherine Taverny, Catherine Boisneau, Sylvain Berail, Christophe Pécheyran, Fanny Claverie and Françoise Daverat $^{2}$

IRSTEA EABX, Aquatic Ecosystems and Global Changes research unit, 50 avenue de Verdun 33612 Cestas France.

david-jose.nachon-garcia@irstea.fr, hilaire.drouineau@irstea.fr, francoise.daverat@irstea.fr

CNRS/ Univ Pau \& Pays Adour/ e2s UPPA, Institut des Sciences Analytiques et de Physicochimie pour l'Environnement et les Materiaux - MIRA, UMR 5254, 64000, Pau, France.

gilles.bareille@univ-pau.fr, helene.tabouret@univ-pau.fr, sylvain.berail@univ-pau.fr, christophe.pecheyran@univ-pau.fr, fanny.claverie@univ-pau.fr

F.D.A.A.P.P.M.A. 33, 10 ZA du Lapin - 33750 Beychac-et-Caillau, France. catherine.taverny@peche33.com

UMR CNRS CITERES 7324, Université de Tours, 33 Allée F de Lesseps, 37200 Tours, France.

catherine.boisneau@univ-tours.fr

${ }^{1}$ David José Nachón, Estación de Hidrobioloxía 'Encoro do Con', Universidade de Santiago de Compostela, Castroagudín, s/n 36617 Vilagarcía de Arousa, España. davidjose.nachon@usc.es 
$22{ }^{2}$ Corresponding author: Françoise Daverat. IRSTEA EABX, Aquatic Ecosystems and Global Changes 23 research unit, 50 avenue de Verdun 33612 Cestas France, tel: +33 (0)5 578927 07. Fax: + 33 (0) 5 24578908 01. françoise.daverat@irstea.fr. 


\section{Abstract}

27 The specific stock composition and dispersion of anadromous fish species aggregations in the marine environment are poorly known, while they can play a major role in the metapopulation dynamics. Otolith microchemistry has proven to be a powerful tool to address natal origins of anadromous fish. We used archived otolith microchemistry to

31 investigate the population-specific composition of European shads (Alosa alosa and Alosa

32 fallax) subadults in the ocean during the 80 's. The allocation of natal origin was addressed relying on contemporary water and juveniles signatures within a Bayesian model. A great discrimination of natal origin was obtained at the Biscay Gulf scale. However, the discrimination of 80's natal origin for the southern rivers with similar geology based on 2013 water and juveniles baselines was doubtful. Our results showed that the most abundant southern populations were dominant, suggesting that population-specific composition was related to population relative abundance. The dispersion in the marine environment was plastic; alternatively shads were found large distances away from their natal rivers, while others remained in the vicinity of their natal river plume. 
Anadromous fish species, such as salmons and shads, share a complex life cycle where reproduction and early life are undertaken in freshwater habitats, whereas growth and maturation are achieved in oceanic habitats. Many anadromous fishes tend to return to spawn to their natal river -a behaviour named homing-, with varying degrees of fidelity, albeit few individuals stray to spawn in a different river than their natal one (Walther et al. 2008; Martin et al. 2013; Martin et al. 2015). While a large amount of information is available concerning the use of freshwater habitats, only few reports are available on how anadromous fishes use the oceanic environment. When oceanic distribution is defined, often with a poor spatial resolution, little is known about the stock-specific ocean migration or the mixing of the fish originating from different rivers (Walther and Thorrold 2010; Loewen et al. 2015; Johnson et al. 2016).

Over the last decades, it has been generally accepted that the return of anadromous fishes to their natal river is influenced by the combination of geomagnetic and olfactory cues (Lohmann et al. 2008; Bandoh et al. 2011; Putman et al. 2013). Recently, it has been suggested that social interactions and collective behaviour could also play an important role in the return of salmons to the river of origin (Berdahl et al. 2016). That is, there is evidence that collective navigation and group effect could facilitate decision-making to find correct migration pathways from the ocean to the native rivers. This group effect could reduce dispersal, which would most likely occur if one individual moved away from the group. In fact, a recent study has shown that although small-scale Chinook salmon Oncorhynchus tshawytscha aggregations in the sea are not entirely uniform, they tend to be composed of individuals from the same natal origin (Johnson et al. 2016). Whether fishes segregate following their natal origin or form mixed stocks at sea has consequences on the possibility 
of exchanges between populations, and more generally demonstrates their dispersal ability at sea (Walther and Thorrold 2010; Loewen et al. 2015; Johnson et al. 2016). Disentangling the habitat occupation and migration patterns at sea of the main source populations in a metapopulation dynamic can provide insight on the relevant management scale and priorities. However, identifying the natal origin of wild anadromous fishes during the ocean growth phase constitutes a real challenge.

Natural tags contained in certain tissues, such as otoliths (calcified structures of the inner ear of teleost fish), could be a good approach to obtain information about the natal origin and subsequent population marine mixing of anadromous species (Hobson 1999; Turner et al. 2015). Otoliths are acellular metabolically inert materials, which grow continuously throughout the life of the fish. The concentration of certain accreted elements in the successive growth layers is largely correlated with their concentration in the ambient water, especially in freshwater (Campana and Thorrold 2001; Walther and Thorrold 2006; Morais and Daverat 2016). Therefore, if there are natal habitats with significant difference in chemical composition, otoliths core from fish hatched in each of them will record for life the unique signatures of each particular natal area, enabling the retrospective identification of natal origin (Campana and Thorrold 2001; Walther et al. 2008; Morais and Daverat 2016). Thus, the unique properties of these calcified pair structures make them especially useful to unravel the life-history features and movement patterns of diadromous fishes at fine spatial scales, such as dispersal capacities, patterns of population connectivity and natal origin of fish (Daverat et al. 2011; Nachón 2017; Randon et al. 2018). Anadromous fishes are often caught as bycatch in coastal fisheries, particularly shads because of their school-forming behaviour (Taverny and Elie 2001; Hasselman et al. 2015; Nachón et al. 2016). These opportunities are usually capitalized to collect various organs or tissues in order to study the life history of the fish caught (Taverny and Elie 2001; Walther and Thorrold 2010; 
Hasselman et al. 2015). Scales and mostly otoliths are thus collected routinely for age determination purposes. After age estimation, these tissues are usually archived in research institutions or museums. Historical otolith collections are precious sources of retrospective information. However, to the best of our knowledge, studies analysing the microchemistry of historical archived otoliths have rarely been addressed (Gao and Beamish 2003; Munro et al. 2005; Loewen et al. 2015).

In the present study, we used natural chemical tags recorded in historical archived otoliths to assess the natal origins of subadults of European shad species collected in the marine environment in the 80 's. The European shads, Allis shad (Alosa alosa) and Twaite shad (Alosa fallax), are a complex of two sympatric sister species of anadromous Clupeidae species. Juveniles develop in freshwater and migrate to the sea during their first year of life (Taverny 1991; Taverny et al. 2000a; Taverny and Elie 2001). During their growth phase, shads aggregate in coastal habitats and undertake back-and-forth movements between the marine and estuarine environments, especially Twaite shad for their first two years of life (Taverny 1991; Taverny and Elie, 2001; Nachón 2017). Then, the growth phase is completed in oceanic habitats until they reach sexual maturity (generally between 3 to 6 years of age) and migrate back to the rivers to spawn (Aprahamian et al. 2003a, 2003b; Baglinière et al. 2003). Both shad species were originally distributed along the Northwest Atlantic coast, from Scandinavia to Morocco as well as in the western Mediterranean (Allis shad) or throughout the Mediterranean (Twaite shad) (Baglinière 2000). Like other diadromous species, the European shads have suffered major declines as their life cycle, using both freshwater and marine ecosystems, exposed them to a suite of accumulation of possible impacts, such as damming of rivers, overfishing, bycatch, deterioration of spawning habitats, etc. (Taverny et al. 2000b; De Groot 2002; Limburg and Waldman 2009). The deleterious effects of these impacts began to be significantly apparent from the late 19th century and intensified during 
the 20th century, leading to considerable extinctions, especially at the extremes of their distribution range, and declines in abundance levels throughout the range of distribution (Baglinière 2000; Taverny et al. 2000b; Aprahamian et al. 2003a). Shad populations were still abundant in France at the end of the 20th century, even though some populations had already suffered significant reductions in the population numbers, such as the Adour and Loire populations, and others had already collapsed or even disappeared, such as the Seine, Brittany and Normandy populations (Taverny 1991; Baglinière 2000; Bruslé and Quignard 2013). During this period, the Gironde system (Dordogne and Garonne rivers) Allis shad populations were the most abundant in Europe (Martin-Vandembulcke 1999; Baglinière 2000; ICES 2015). However, from the year 2000 onwards, the Garonne and Dordogne Allis shad populations collapsed (Rougier et al. 2012) and the abundance of other French shad populations has also decreased dramatically (Cellule Migrateurs Charente Seudre 2017; Legrand and Besse 2018).

During their oceanic phase, the habitats used by subadults of both species are located in the vicinity of the river mouths of most important spawning grounds, such as Gironde system, Charente, Loire and Vilaine rivers, along the French Atlantic coast of the Bay of Biscay (Taverny 1991; Taverny and Elie 2001). The presence of subadults in marine habitats connected to an estuary would suggest that fishes stay close to their natal river basin (Taverny 1991; Taverny and Elie 2001). Recent studies that have revealed that Allis shad formed a meta-population where exchanges of adults primarily occurred between neighbouring rivers (Martin et al. 2015; Randon et al. 2018), would support this hypothesis. Genetic tools suggested that Twaite shad formed more structured populations than Allis shad populations, meaning that exchanges between populations should be more intense for the latter (Jolly et al. 2012). So far, there is no knowledge on whether straying is favoured by a mixing of the populations of shads from different natal origin at sea or if shads are straying 
from distinct marine habitats. Understanding the population-specific dispersal capacities in the ocean is thus required. Allis shad juveniles from a Moroccan population displayed migrations of $600 \mathrm{~km}$ along the coast between their natal river and their marine habitats, demonstrating the dispersion ability of the species (Sabatié 1993). In addition, some Allis shad adults would be able to enter rivers for spawning at a distance of more than $700 \mathrm{~km}$ from their natal river (Martin et al. 2015). Marine bycatches of both species have been documented several hundred kilometres away from their most likely rivers of origin (La Mesa et al. 2015; Nachón et al. 2016).

In the present study, the goals were first, to address the utility of archive otoliths in assigning the natal origin of European shads captured 30 years ago in the marine environment, when the Gironde shad populations were still abundant, and second, to investigate the distribution of Allis shad and Twaite shad subadults at sea following their natal origin in order to understand the extent of mixing or segregation of European shad populations. For that purpose, we coupled the otolith elemental and isotopic microchemistry with a Bayesian mixing model following Martin et al. (2015) and Randon et al. (2018).

\section{Material and methods}

\section{Study area}

The Bay of Biscay is a large open oceanic area located at the east of the North Atlantic Ocean (western part of Europe), which expands from north coast of Spain (from Cape Ortegal, $\sim 42^{\circ} \mathrm{N},-9^{\circ} \mathrm{W}$ ), to the west coast of France (up to Finistère in Brittany, $\sim 48^{\circ} \mathrm{N}$ and $1^{\circ} \mathrm{E}$ ). This bay has a contrasted morphology as the continental shelf (depths $<200 \mathrm{~m}$ ) is very narrow in the south, along the coast of Spain (10-65 km wide), whilst widens northward along the French coast, from $20 \mathrm{~km}$ in the southern part (Capbreton Canyon) to over $200 \mathrm{~km}$ in the northern part (Koutsikopoulos and Le Cann 1996; Le Pape et al. 2003; Bertin et al. 2012). 
165 Our study focused on the French part of the Bay of Biscay (Fig. 1). Surface coastal waters of this area receive a strong freshwater run-off from outflow plumes of the main rivers, with Loire River and Gironde system providing $75 \%$ of the freshwater input (Ayata et al. 2010; Laiz et al. 2014; Costoya et al. 2017). Other rivers along the coast as Vilaine, Sèvre Niortaise, Charente, Adour and Nivelle rivers have more limited contributions in terms of freshwater run-off. The strong density gradients, which occurred in the vicinity of the outflow plumes of the Loire River and Gironde system, lead to extensive density currents over the shelf, essentially in a northwards direction (Koutsikopoulos and Le Cann 1996; Ayata et al. 2010). The regions under the influence of the river plume, especially those around the Vilaine River, Loire River and Gironde system, are highly productive pelagic areas, mainly for plankton (both phytoplankton and zooplankton) and small pelagic fishes (Motos et al. 1996; Irigoien et al. 2008).

\section{Source of available shad samples}

Archived otoliths from subadults of both shad species captured as bycatch in the late 1980s during research campaigns of "Institut Français de Recherche pour l'Exploitation de la Mer" (IFREMER) throughout the French continental shelf of the Bay of Biscay were selected as biological material (Taverny 1991; Taverny and Elie 2001). Bottom trawl scientific surveys (RESSGASC and SOLDIF) were conducted using random stratified sampling designs and targeting demersal or benthic species rather than pelagic species.

RESSGASC campaign (from August 1986 to Mars 1989) covered practically the entire coast, approximately $430 \mathrm{~km}$ (from the Morbihan Cape at $48^{\circ} \mathrm{N}$ to the North of the Arcachon Basin at $45^{\circ} \mathrm{N}$ ), in a range of depths between $11 \mathrm{~m}$ and the $100 \mathrm{~m}$ isobaths (Fig. 1). The gear used in this campaign was a Vendée bottom trawl net of $25 \mathrm{~m}$ of headline and a $55 \mathrm{~mm}$ stretched mesh in the cod end. Of the 427 completed stations over all period, Allis shad and Twaite shad were captured in 59 and 55 locations respectively, with 18 shared locations. Catches 
averaged 4 fishes per trawl date for both species, with the largest collections accounting 21 and 45 individuals of Allis shad and Twaite shad respectively (total $n=254$ Allis shad; $n=$ 224 Twaite shad)

SOLDIF campaign (from May 1988 to February 1989) was limited to a smaller sampling area, both with respect to the length, around the mouth of the Vilaine and Loire rivers $\left(47^{\circ} 17^{\prime} \mathrm{N}\right)$, and the depth, from outside the coastal zone to depths of less than $50 \mathrm{~m}$ (Fig. 1). Two gears were used in this sampling campaign: a $25 \mathrm{~m}$ double bottom trawl with $20 \mathrm{~mm}$ stretched mesh in the cod end and a $3 \mathrm{~m}$ long beam trawl of $1 \mathrm{~mm}$ stretched mesh in the cod end. Of the 168 completed stations over all period, Allis shad and Twaite shad were captured in 16 and 15 locations respectively, with 6 shared locations. Catches in these campaigns averaged 3 and 2 individuals per day for Allis shad and Twaite shad respectively, with the largest collection of 15 and 5 individuals of Allis shad and Twaite shad respectively (total $n=$ 51 Allis shad; $n=31$ Twaite shad).

The identification of the species was carried out by Taverny (1991) based on the relationship between total length and gillrakers number along the first gill arch. All captured individuals were in the sub-adult phase (Taverny 1991; Taverny and Elie 2001). The age ranged from 2 to 5 years for Allis shad and from 2 to 6 years for Twaite shad, with more than $80 \%$ of Allis shad individuals aged between 2 and 3 years, and more than $80 \%$ of Twaite shad aged between 3 and 4 years (Taverny 1991; Taverny and Elie 2001). Full details of the sampling campaigns carried out in marine environments together with biometrical and demographic characteristics of all individuals are given in Taverny (1991) and Taverny and Elie (2001).

In total, sagittal otoliths of 209 Allis shad (RESGASC, $n=160$; SOLDIF, $n=49$ ) and 166 Twaite shad (RESGASC, $n=140$; SOLDIF, $n=26$ ) were selected from the overall archives (1986-1989, Fig. 1). Samples selection was based on biometry and location catch data availability. Allis shad subadults belonged to 1982-1986 cohorts while Twaite shad subadults 
belonged to $1982-1987$ cohorts. More than $80 \%$ of the samples from both species belonged to the 1985 year class (see online supplementary Table $\mathrm{S}^{3}$ ).

\section{Otolith preparation and microchemistry analysis}

The archived otoliths from Taverny works (Taverny 1991; Taverny and Elie 2001) have previously been used in toto for age reading. Untreated otoliths have been stored dry in individually labelled paper envelopes since then. Thus, the absence of chemical or physical treatments on the otolith ensured the integrity of otoliths chemical composition. Furthermore, targeted elements of this study $\left({ }^{87} \mathrm{Sr}:{ }^{86} \mathrm{Sr}, \mathrm{Sr}: \mathrm{Ca}\right.$ and $\mathrm{Ba}: \mathrm{Ca}$ ratios) should be stable over 30 years of time in archived otoliths under correct storage conditions, as strontium and barium substitute calcium in otoliths (Kennedy et al. 2000; Campana and Thorrold 2001). Consequently, one sagittal otolith from each pair was randomly selected for microchemistry purposes. Selected otoliths were rinsed with ultrapure water and air-dried during $24 \mathrm{~h}$ under a laminar flow hood. This process and the following ones were carried out in class 10000 clean room, in order to avoid any possible contamination. Posterior otolith preparation was carried out according to Martin et al. (2015). To analyse ${ }^{87} \mathrm{Sr}:{ }^{86} \mathrm{Sr}, \mathrm{Sr}: \mathrm{Ca}$ and $\mathrm{Ba}: \mathrm{Ca}$ ratios, two C-shaped ablation trajectories of $60 \mu \mathrm{m}$ thick were performed $40 \mu \mathrm{m}$ away from the core. A High Resolution (Thermo Scientific, USA) inductively coupled plasma quadrupole mass spectrometer (HR-ICP-MS) was used to analyze Sr:Ca and Ba:Ca ratios. The HR-ICP-MS was coupled to a UV high-repetition-rate femtosecond laser ablation (fs-LA) system (Nexeya SA, Canejan, France). A Nu-Plasma multicollector inductively-coupled-plasma massspectrometer (MC-ICP-MS, Nu Instruments, UK) coupled to a UV high-repetition-rate femtosecond laser ablation (fs-LA) system (Nexeya SA, Canejan, France) was used to analyze ${ }^{87} \mathrm{Sr}:{ }^{86} \mathrm{Sr}$. Analytical process can be found in Martin et al. (2015).

\footnotetext{
${ }^{3}$ Supplementary data are available with the article.
} 


\section{Baseline samples and statistical analyses}

The natal origin of each individual caught at the sea during the 1980s was assigned using a Bayesian mixing model relying on a water and otolith chemical database $\left({ }^{87} \mathrm{Sr}:{ }^{86} \mathrm{Sr}, \mathrm{Sr}: \mathrm{Ca}\right.$ and $\mathrm{Ba}: \mathrm{Ca}$ ratios), from water samples and juvenile otoliths of Allis shad, as well as both adults collected in 18 rivers throughout its 2000s distribution range (Randon et al. 2018). Since no model of microchemical data was available for Twaite shad, the same Allis shad model was also used for this species. This was justified by the fact that there was no ${ }^{87} \mathrm{Sr}:{ }^{86} \mathrm{Sr}$ biological fractionation (Kennedy et al. 2000; Walther and Thorrold 2008; Pouilly et al. 2014). In consequence, the otoliths of both shad species from a given system would share the same ${ }^{87} \mathrm{Sr}:{ }^{86} \mathrm{Sr}$ ratios. In addition, Strontium incorporation rate was found to be the same for both species (Lochet 2006). Because of the close phylogenetic relationship of both species, we can assume that it would be similar for Ba (Bentzen et al. 1993; Alexandrino et al. 2006; Chang and Geffen 2013). According to the available literature, both species occupied to a large extent the same rivers in the 1980s as in the 2000s (Taverny 1991; Baglinière 2000; Bruslé and Quignard 2013). Thus we can assume that our model includes all natal river populations that could most likely be found in the marine stock mix during the 1980s.

In our work, the sea caught subadults were grouped according to the proximity to the river plumes. Thus, our samples were grouped into two zones that mimic two new capture rivers. A Bay of Biscay Center (BBC) group was created for each species (Allis shad, $n=64$; Twaite shad, $n=127)$. It included all the catches located between $45-46^{\circ} \mathrm{N}$, likely originating from the Charente River and the Gironde system. Although located in the southern Bay of Biscay where there were no marine catches, the rivers of the Adour basin and the Nivelle River could also potentially contribute individuals to the mixture of marine individuals located in the Bay of Biscay Center. The second group, the Bay of Biscay North (BBN) 
included all individuals caught between $46-48^{\circ} \mathrm{N}$ (Allis shad, $n=145$; Twaite shad, $n=39$ ), which would likely originate from Brittany and Normandy rivers and from Loire River.

The model was run with all available samples, i.e., using baseline datasets (Allis shad juveniles, $n=61$ and water, $n=61$ ), otolith microchemistry of Allis shad adults with unknown origins $(n=615)$ from Randon et al. (2018) and the addition of 209 Allis shad and 166 Twaite shad sea samples grouped following their capture zone. We established a period $p$ (before 1990, after 2005) effect in the probabilities of origin to account for a possible modification of the homing dynamics along the time. The model was carried out employing the software JAGS and was run by runjags package (Plummer 2003; Denwood 2013), which promotes the communication between JAGS and R statistical software (R Development Core Team, R.3.1.1, 2014). Three independent Monte Carlo Markov Chain (MCMC) chains were run in parallel for 20000 iterations after a burn-in period of 10000 iterations to draw simulations from Bayesian posterior distributions. A vector $\{\theta \mathrm{c}, \mathrm{p}\}$ denoting the probabilities that a given fish captured in a river (c) during each period (p) was born in each of the kb river of the water baseline was included for each catch river and period. Each subadult caught in a marine region during the period $<1990$ was reassigned to one or more natal rivers, among the 18 possible natal rivers included in the baseline dataset, at the end of the iterative process. Thus, the frequency of reassignment of a fish $\mathrm{f}$ in a source $\mathrm{k}$ was defined as the number of iterations of the MCMC in which the fish $\mathrm{f}$ was reassigned into a source $\mathrm{k}$, divided by the total number of iterations produced during the MCMC. As a result a reassignment probability of $\mathrm{f}$ in $\mathrm{k}$ is obtained. This probability was calculated for each of the fish and sources, in such a way that each fish has at the end an Ff vector containing the kb reassignment probabilities (one for each river of the baseline). Finally, each fish was assigned to its natal origin based on the maximum posterior classification probability. We then calculated the proportional representations of each identified source stock to the marine sectors defined. A matrix 
containing the Ff of each fish in rows and natal river in columns was created. Thus, we used Spearman's correlation test (threshold 0.05) to calculate the correlation between each of the pairs of columns. There is confusion during the process of reallocation if there is a strong and positive correlation between the corresponding rivers, while the rivers are well discriminated if there is a strong and negative correlation. For more detailed descriptions about statistical calculations of the Bayesian model see Randon et al. (2018).

\section{Results}

\section{Model requirements and probabilities of reallocation}

The model satisfied all the requirements, such as convergence under the Gelman-Rubin diagnostic (see Randon et al. 2018 for more details about model requirements), in order to provide estimates of the proportion of individuals in each marine region according to their natal origin. Maximum posterior conditional assignment probabilities (i.e., the probability of assignment to each natal river) from the Bayesian mixing model were greater than 0.7 for $92.3 \%(n=193$ of 209 individuals $)$ and $81.3 \%(n=135$ of 166 individuals $)$ for Allis shad and Twaite shad respectively. Thus, the majority of subadults caught in the marine environment were assigned to a natal river with high degrees of confidence. Slight confusions were found as shown by the correlation matrix (Fig. 2). Confusions occurred usually between neighbouring rivers as between the Nive and Saison rivers, although there were also some confusions between rivers from distant basins (Charente-Saison or Vire-Vilaine). Nevertheless, northern French rivers (from Loire River upwards) were well discriminated from southern French rivers (from Charente River downwards). 
Chemical signatures from the otoliths revealed that Allis shad and Twaite shad subadults caught in the Bay of Biscay originated from Southern rivers (Figs. 3, 4 and 5). The rivers in the Northern part of our study area (Loire River, Brittany and Normandy rivers) did not provide any fish of both shad species to the samples in the marine environment.

\section{Allis shad subadults}

When analysing all the probabilities of assignment of each fish we observed a clear dominance of assignment of the individuals to the Adour River in both marine regions (Fig. 3). With respect to the maximum probabilities of assignment of each individual the dominance of the Adour River was certified, with a percentage of $95.69 \%$ ( $n=200$ individuals), and the remaining individuals originated from the Charente $(3.35 \%, n=7$ individuals), Nivelle $(0.48 \%, n=1$ individual) and Aveyron rivers $(0.48 \%, n=1$ individual). Slight differences in the stock composition were detected according to the geographical region (Fig. 4). In the Bay of Biscay North, 97.24\% of individuals ( $n=141$ individuals) were assigned to the Adour River, while in the Bay of Biscay Center $92.19 \%$ of individuals $(n=59$ individuals) were assigned to the Adour River. In Bay of Biscay North, the Aveyron $(0.7 \%, n$ $=1$ individual $)$ and the Charente River $(2.07 \%, n=3$ individuals) natal origins were observed while in Bay of Biscay Center, Charente $(6.25 \%, n=4$ individuals) and the Nivelle River $(1.56 \%, n=1$ individuals) individuals completed the specific composition.

\section{Twaite shad subadults}

Similarly to Allis shad, all the probabilities of assignment of each fish showed that almost every individual originated from one source, in this case the Oloron River (Fig. 3). Oloron river also belongs to the Adour basin to the south of the study area. Maximum probabilities of 
assignment of each individual showed that a percentage of $95.78 \%$ of individuals $(n=159$ individuals) were assigned to the Oloron River. The remaining individuals originated from the Charente River (4.22\%, $n=7$ individuals). In both marine regions, individuals were

\section{Discussion}

\section{Population-specific proportions at sea}

Despite the vast spatial coverage of the sampled area (525 sampling stations in a stratified random fashion), the data collection was not exhaustive (especially in the Southern area)

which could have biased the stock composition estimates. However, the access to any shad data at sea was and is still nowadays a major challenge that deserves to be fully addressed with an appropriate sampling plan.

In the northern region of the Bay of Biscay, where a large proportion of the samples were located (especially for Allis shad), the absence of individuals native of northern French rivers was observed. This result was consistent with the relative abundance of shad populations along the Bay of Biscay in the 80's. Vire and Brittany rivers shad populations were nearly extinct and Loire River shad populations had very low abundance compared to the Southern rivers shad populations (Taverny 1991; Baglinière 2000; Bruslé and Quignard 2013). The very contrasted geologic and chemistry differences between Northern granitic French rivers (Loire and northwards) and Southern sedimentary French rivers (Charente and southwards) enabled a robust and accurate discrimination of natal origins between these two main groups 
of rivers (Martin et al. 2015; Willmes et al. 2018). While Northern granitic French rivers have high ${ }^{87} \mathrm{Sr}:{ }^{86} \mathrm{Sr}$ ratios between $0.71160 \pm 1.00 \mathrm{E}-04$ and $0.71429 \pm 1.01 \mathrm{E}-04$, Southern sedimentary French rivers have low Sr values between $0.70823 \pm 5.70 \mathrm{E}-05$ and $0.71037 \pm$ 1.22E-04 (Martin et al. 2015). Our Bayesian model of natal origin was mainly driven by ${ }^{87} \mathrm{Sr}:{ }^{86} \mathrm{Sr}$ ratios, while $\mathrm{Sr}: \mathrm{Ca}$ and $\mathrm{Ba}: \mathrm{Ca}$ ratios complemented the discrimination (Martin et al. 2015). ${ }^{87} \mathrm{Sr}:{ }^{86} \mathrm{Sr}$ ratios were considered as "ideal" spatial markers for characterizing natal sources since they reflect the different bedrock geologies and tended to be stable over ecological timescales (Kennedy et al. 2000; Zimmerman et al. 2013; Loewen et al. 2015). Therefore, populations of the Southern sedimentary French rivers undoubtedly supplied both species in the marine areas.

\section{Interpretation of natal origin of shad and metapopulation dynamics at sea}

Looking at a finer geographical scale, our results showed that an overwhelming majority of Allis and Twaite shad subadults caught at sea were assigned to only two natal sources of the Southern sedimentary French rivers group, identified by the model as the Adour River and Oloron River for Allis shad and Twaite shad respectively. The dominance of a limited number of river populations in the mixed stock at sea was already observed for a closely related species, the American shad, Alosa sapidissima (Walther and Thorrold 2010). Although a wider range of ages were considered in the present study, European shads and American shad showed the same metapopulation dynamics with few source populations and several sinks. This similarity of dispersal and behavioural capabilities during immature stages could be related to the phylogenetic proximity between American shad and European shads (Bentzen et al. 1993).

Unexpectedly, only a small percentage of Allis shad subadults were assigned to the populations of the Gironde system, which was considered to be the most important Allis shad 
populations in Europe in the 80's (Martin-Vandembulcke 1999; Baglinière 2000; ICES 2015). In the same way, a low abundance of Twaite shad subadults originating from populations of the Gironde system was observed. Although the available data on the abundance of Twaite shad in freshwater during the 1980s were scarce, the reported 13-15 tonnes of commercial catch of Twaite shad adults and an estimated recruitment of 9.5-22.5 millions of Twaite shad juveniles in the Gironde system, suggested that Twaite shad populations in this system were also abundant (Taverny, 1991; Baglinière et al. 2001). The subadults samples from the present study belonged to a reduced numbers of cohorts (19821986 and 1982-1987 for Allis shad and Twaite shad respectively), 1985 being the dominant cohort for both species. The dominance of subadults Adour and Oloron origin for Allis shad and Twaite shad respectively could be explained by a difference in abundance and recruitment success between populations of Adour and Oloron rivers and Allis shad and Twaite shad populations from Gironde system during 1982-1986 period of time. Despite the fact that Allis shad total commercial catches were 30 times greater in the Gironde system (708.4 metric tons, 1983-1987 period) than in the Adour River (24.3 metric tons, 1985-1987 period, see Elie et al. 2000; Baglinière et al. 2003 and references therein), the relative fishing effort would rather result in only a factor 4 relative shad abundance between both River systems (Albiges et al. 1985; Prouzet et al. 1994; Castelnaud et al. 2001). There was no available catch data for the Twaite shad in the Oloron River, and therefore no conclusions could be drawn about the difference in relative abundance between Oloron River and the Gironde system Twaite shad abundances. Juvenile shad abundance index in the Gironde estuary showed considerable fluctuations between cohorts, with lowest values in 1983 and 1986 and in 1984 for Allis shad and Twaite shad respectively (Lambert et al. 1997). Anthropogenic juvenile mortality was particularly high in the Gironde system during 1985, when most of our samples were hatched, as it was estimated that 1.2 million individuals of 
Allis shad juveniles and 880000 individuals of Twaite shad juveniles died from water intake from the nuclear power plant of Blayais (Taverny, 1991). Thus, the hypothesis of a greater abundance of Adour origin Allis shad 1982-1986 cohorts and Twaite shad 1982-1987 cohorts could be explained by the chaotic dynamics of shad populations, a clupeid species (Sabatié 1993; Rougier et al. 2012; Nachón et al. 2016). However, data on juvenile abundance was totally lacking for the Adour estuary (common estuary to Adour River and Oloron River), which did not allow us drawing a final conclusion on the relative abundance of juveniles of both species between the two main natal rivers (Adour River for Allis shad and Oloron River for Twaite shad) and Gironde systems for studied cohorts. Alternatively, a great recruitmentstock relationship and high survival for Allis shad and Twaite shad individuals originating from Adour River and Oloron River respectively and the opposite situation for shad populations of the Gironde system could drive to a situation in which Allis shad population from Adour River and Twaite shad population from Oloron River acted as a source and Allis shad and Twaite populations from the Gironde system as a sink. Unfortunately, homing behaviour in these rivers during the 80's was not available to discuss this hypothesis.

An alternative hypothesis to explain the dominance of Adour River and Oloron River natal origin in the marine samples would be the allocation confusion between these rivers and rivers from Gironde system. The allocation of 80's fish natal origins in the present study was based on contemporary references (water and juveniles) because of the lack of available 80's references. The chemical baselines used in previous studies were adapted to the contemporary context of the Allis shad populations and the hydromorphological characteristics of the rivers, and based on discrete samples collected during the spawning period in the known spawning grounds (Martin et al. 2015; Randon et al. 2018). Although European shads exhibited a high interannual fidelity to spawning grounds, interannual hydrological fluctuations and density-dependent processes could induce changes in the 
selection of spawning grounds (Cassou-Leins et al. 2000). Hence, the number and spatial coverage of spawning areas in the 1980s were likely different in the Adour system and the Gironde system than in recent years, mainly due to hydrological and abundance changes between the two periods. In fact, considerable inter-annual fluctuations have been detected in the occupation of the spawning grounds by Allis shad over time in the Gironde system (Cassou-Leins and Cassou-Leins 1981; Belaud et al. 2001; Taverny 1991). This situation was more confusing for the Twaite shad all the more because Twaite shad spawning grounds were found more downstream, where the homogeneity of water signatures increased as the mix of tributaries contribution increased. Yet, the knowledge of the different spawning grounds occupied during the 80 's in the French Southern Rivers was not available.

Adour and Garonne Rivers chemical signatures could be discriminated considering a recent period of a few years, however, Martin et al. (2015) already pointed that differences between $\mathrm{Sr}$ isotopes, $\mathrm{Sr}: \mathrm{Ca}$ and $\mathrm{Ba}: \mathrm{Ca}$ water composition among Southern sedimentary French rivers group were tiny (Table 1 and Fig. 6). More specifically, close values of water composition were measured for Adour River, Garonne River and Dordogne River (see online supplementary Table S23 ). Randon et al. (2018) observed slight allocation confusions for origin allocations of contemporary samples, being greater between Garonne River and Adour River or between Adour River and Oloron River, while Dordogne and Charente showed very slights confusions issues. But ultimately, allocations confusions should remain low enough to discriminate Adour River and Garonne River origins for contemporary shads according to Randon et al. (2018). Strontium isotopes values for the river main stretches could be affected by the relative contribution of the tributaries flow to the total flow. Factors such as rock type, weathering velocities, or the magnitude of flow variation between sessions were found to affect the composition of strontium isotopes water values (Walther and Limburg 2012). Rivers from Gironde system have suffered a flow decrease (especially the Garonne River), a 
systematically increase of water uptake for agricultural irrigation, granulate extraction and damming (Jalón-Rojas et al. 2015; Schmidt et al. 2016). There anthropogenic pressures might have slightly modified $\mathrm{Sr}$ isotopes values to the extent to add confusion in the discrimination between Southern sedimentary French rivers chemical signatures. We cannot exclude the hypothesis that the present study might have failed to discriminate precisely shads natal origins provided the lack of 80 's references such as exhaustive water composition of all potential spawning grounds and juvenile fish otolith chemical composition. However, the allocation of natal origin was very accurate between northern and southern Rivers, allowing the interpretation of stock mixing at sea.

In conclusion, given the uncertainties to accurately discriminate individual originated from the Southern sedimentary French rivers group to a more finer scale (specific river), from now on we will refer to southern populations of Allis shad.

\section{Population-specific dispersal capacities at sea}

Our results overall suggested that large populations resulted in large dispersion of individuals at sea. Marine habitat occupation was plastic, with a proportion of Allis shad and Twaite shad subadults from Southern rivers populations remaining in the vicinity of their natal river estuary plume and other subadults using marine habitats further away, covering distances up to $400-600 \mathrm{~km}$. The pattern and distances travelled were identical to those shown by the predominant one-year-old population American shad along the North American east coast (Walther and Thorrold 2010), reinforcing the similar dynamics functioning hypothesis through the phylogenetical similarity between these species.

Based on our results we suggested a modification of a previous hypothesis stating that European shads would aggregate following natal origin in the vicinity of their natal river 
estuary (Taverny and Elie 2001; Lassalle et al. 2008; Rougier et al. 2014). An alternative hypothesis consistent with our results would be two population-specific dispersal behaviours. The first type of behaviour could be called resident gregarious, formed by individuals with the same natal origin and remaining in the vicinity of the natal estuary. The second type of behaviour could be called dispersive gregarious, formed by individuals with the same natal origin but travelling longer distances away from their natal estuaries. The underlying mechanism driving the existence of two types of behaviours or ecotypes should be explored in future studies. Both abiotic factors, such as the predominant northward currents (Koutsikopoulos and Le Cann 1996), and biotic factors such as density-dependent processes, genetic components, or foraging may be involved (Taverny and Elie 2001; Johnson et al. 2016; Huntsman et al. 2017). The discovery of this type of important latitudinal displacements contrasted with a previous study carried out in the Bay of Biscay, which suggested that both shad species primarily performed seasonal longitudinal movements and barely performed latitudinal displacements (Trancart et al. 2014).

Our results supported the first description of the population-specific dispersal capabilities of European shads subadults at sea. A previous study showed that juveniles Allis shad from the Sebou River in Morocco migrated southwards for about $600 \mathrm{~km}$ until they reached the upwelling areas rich in nutrients (Sabatié 1993). However, Sabatié (1993) did not carry out any specific studies on natal origin and suggested that the Allis shad individuals present in these upwelling areas would most likely originated from the only river (Sebou River) with a stable and abundant presence of Allis shad along the Atlantic coast of Morocco. Marine bycatches of European shads have also been documented several hundred kilometres from the most likely source rivers (La Mesa et al. 2015; Nachón et al. 2016). Based on natal origin determined by otolith microchemistry, Allis shad individuals were also found to migrate considerable distances along the marine environment from their natal origin river to their 
spawning river (Martin et al. 2015). Similarly, genetic studies suggested that Twaite shad individuals could cover distances of hundreds of kilometres between their natal rivers and their spawning river (Jolly et al. 2012).

\section{Implications of the population-specific composition at sea on the metapopulational dynamics at continental scale}

Whether the population specific dominance of Southern rivers populations in the Bay of Biscay promoted straying and subsequent colonization of some rivers remains to be tested. In the 80 's, Brittany Allis shad populations were nearly extinct, but since the $2000 \mathrm{~s}$, small populations started to establish again. Recent studies showed that Allis shad populations in Brittany exhibited a high degree of homing, with small exchanges of spawners (Randon et al. 2018). The recovery of a depleted population is driven by two different processes: the increase of abundance of residual populations that had remained in the considered rivers and/or coastal nearby areas, or alternatively by immigration of strayers originating from nearby populations (Belliard et al. 2009; Perrier et al. 2009; Andrée et al. 2011). The reintroduction success by straying relied on the proportion of strayers provided to the depleted population as well as on the proximity of neighbouring populations (Hamann and Kennedy 2012; Keefer and Caudill 2014). The colonisation of Brittany Rivers in the 1980s by Allis shads from Southern Rivers, located at sea in vicinity of river plumes, could explain the recovery of Brittany Rivers.

In the hypothesis of a composition of marine stocks linked to the abundance of shads in the continental environment, the dispersal capacities in the marine environment could have changed in the current context of the collapse of the Gironde system populations and generalised French populations abundance decrease (Rougier et al. 2012; Cellule Migrateurs 
527 Charente Seudre 2017; Legrand and Besse 2018). Weak dispersion in the marine environment would explain why straying behaviour was mainly observed between neighbouring rivers nowadays (Randon et al. 2018). Even the Dordogne River, which has been identified as the main source river in the metapopulation dynamics of Allis shad, produces strayers that mostly enter in other river (Garonne River) of the same basin (Randon et al. 2018). The virtual absence of strayers from southern rivers in northern rivers (Randon et al. 2018), was consistent with the hypothesis of a lesser dispersal capacities at sea. It would be interesting to find out if the dispersion of Southern rivers populations has changed over time. Whether dispersion at sea is determined by abundance (density dependence) or another factor remains to be tested. Therefore, future studies on stock-composition at sea are necessary to understand how erratic individuals exchange between the different local populations forming Allis shad metapopulation occurs. Regarding Twaite shad, it is also essential to carry out studies on the natal homing to elucidate if this species shows metapopulational behaviour similar to Allis shad.

In conclusion, the results of this paper show that the subadults of the European shads captured at sea presented a limited diversity of natal origins. Most of the Allis shad subadults came from the Adour River while most of the Twaite shad subadults originated from the Oloron River. There were two hypotheses to explain the results: either the results reflected the reality of the populations and expressed differences of survival between the populations of the Southern Rivers or the alternative hypothesis was that it resulted from a confusion of allocation between the rivers of the South due to the lack of references to the chemistry of the water and the otoliths of the juveniles during the 80 's. A robust discrimination of Northern and Southern rivers suggested that the population-specific composition of European shads at sea was influenced by abundance in the continental environment. As a result of this abundance, there was a great diffusion in the marine environment, with most abundant 
populations dispersing from areas close to the native river to areas hundreds of kilometres away. Stock specific composition at sea is important for management and may be useful to 554 prioritize protection of main population sources of shads.

\section{Acknowledgements}

556 This study was co-funded by Agence de l'Eau Adour Garonne and Nouvelle Aquitaine 557 Region within the SHAD'EAU FAUNA projects. Thanks to the biostatistics engineer 558 Sebastien Boutry from IRSTEA Center of Bordeaux for his help in producing the graphics. 559 Special thanks go to the technician Guillaume Lefebvre, also from IRSTEA Center of 560 Bordeaux, for his help in drawing the maps. We are also grateful to Eric Rochard, Patrick 561 Lambert, Alexis Paumier and Mélanie Gaillard from IRSTEA Center of Bordeaux for fruitful 562 discussions. Finally, we are grateful to the Associate Editor and reviewers for their relevant remarks and advice that largely improved the quality of this work. 


\section{References}

Albiges, C., Rochard, E., and Castelnaud, G. 1985. Etude de suivi halieutique de l'estuaire de la Gironde 1985. Groupement de Bordeaux, Equipe Estuaires - Division A. L. A., Bordeaux.

Alexandrino, P., Faria, R., Linhares, D., Castro, F., Le Corre, M., Sabatié, R., Baglinière, J.L., and Weiss, S. 2006. Interspecific differentiation and intraspecific substructure in two closely related clupeids with extensive hybridization, Alosa alosa and Alosa fallax. J. Fish. Biol. 69: 242-259. doi:doi.org/10.1111/j.1095-8649.2006.01289.x.

Andrée, K.B., López, M.A., Alexandrino, P., Faria, R., and Gisbert, E. 2011. A preliminary genetic analysis of a recently rediscovered population of the Twaite shad (Alosa fallax) in the Ebro river, Spain (Western Mediterranean). J. Appl. Ichthyol. 27: 21-23. doi:10.1111/j.1439-0426.2011.01847.x.

Aprahamian, M.W., Aprahamian, C.D., Baglinière, J.L., Sabatié, R., and Alexandrino, P. 2003a. Alosa alosa and Alosa fallax spp.: literature review and bibliography. R\&D Technical Report W1-014/TR, Environment Agency, Warrington.

Aprahamian, M.W., Baglinière, J.L., Sabatié, R., Alexandrino, P., Thiel, R., and Aprahamian, C.D. $2003 b$. Biology, Status, and Conservation of the Anadromous Atlantic Twaite shad Alosa fallax fallax. In Biodiversity, status and conservation of world's shads. Edited by K.E. Limburg and J.R. Waldman. American Fisheries Society Symposium 35, Bethesda. pp. 103-124.

Ayata, S.D., Lazure, P., and Thiébaut, É. 2010. How does the connectivity between populations mediate range limits of marine invertebrates? A case study of larval 

dispersal between the Bay of Biscay and the English Channel (North-East Atlantic). Prog. Oceanogr. 87(1-4): 18-36. doi:10.1016/j.pocean.2010.09.022.

Baglinière, J.L. 2000. Le genre Alosa sp. In Les aloses (Alosa alosa et Alosa fallax spp.). Écobiologie et variabilité des populations. Edited by J.L. Baglinière and P. Elie. CEMAGREF-INRA Editions, Paris. pp. 3-30.

Baglinière, J.L., Sabatié, M.R., Aprahamian, M.W., Alexandrino, P., Aprahamian, C.D., Assis, C.A., Cassou-Leins, J.J., Le Corre, M., Mennesson-Boisneau, C., MartinVandembulcke, D., Rochard, E., and Teixeira, C. 2001. Guide pour l'interpretation des écailles et l'estimation de l'âge chez les aloses (Alosa spp.) de la Façade Atlantique-est et de la Méditerranée-ouest. Bull. Fr. Pêche Piscic. 357/360: 485-527. doi:10.1051/kmae:2001001.

Baglinière, J.L., Sabatié, M.R., Rochard, E., Alexandrino, P., and Aprahamian, M.W. 2003. The allis shad Alosa alosa: biology, ecology, range, and status of populations. In Biodiversity, status and conservation of world's shads. Edited by K.E. Limburg and J.R. Waldman. American Fisheries Society Symposium 35, Bethesda. pp. 85-102.

Bandoh, H., Kida, I., and Ueda, H. 2011. Olfactory responses to natal stream water in sockeye salmon by BOLD fMRI. PLoS ONE, 6(1): e16051. doi:10.1371/journal.pone.0016051.

Belaud, A., Carette, A., Cassou-Leins, F., and Cassou-Leins, J.J. 2001. Choix des sites de fraie par la grande alose (Alosa alosa L.) en moyenne Garonne. Bull. Fr. Pêche Piscic. 362/363: 869-880. doi:10.1051/kmae:2001024. 
Belliard, J., Marchal, J., Ditche, J.M., Tales, E., Sabatié, R., and Baglinière, J.L. 2009. Return of adult anadromous allis shad (Alosa alosa L.) in the river Seine, France: a sign of river recovery?. River. Res. Appl. 25(6): 788-794. doi:10.1002/rra.1221.

Bentzen, P., Leggett, W.C., and Brown, G.G. 1993. Genetic relationships among the shads (Alosa) revealed by mitochondrial DNA analysis. J. Fish. Biol. 43: 909-917. doi:10.1111/j.1095-8649.1993.tb01165.x.

Berdahl, A., Westley, P.A., Levin, S.A., Couzin, I.D., and Quinn, T.P. 2016. A collective navigation hypothesis for homeward migration in anadromous salmonids. Fish. Fish. 17(2): 525-542. doi:10.1111/faf.12084.

Bertin, X., Bruneau, N., Breilh, J.F., Fortunato, A.B., and Karpytchev, M. 2012. Importance of wave age and resonance in storm surges: The case Xynthia, Bay of Biscay. Ocean. Model. 42: 16-30. doi:10.1016/j.ocemod.2011.11.001.

Brennan, S.R., Torgersen, C.E., Hollenbeck, J.P., Fernandez, D.P., Jensen, C.K., and Schindler, D.E. 2016. Dendritic network models: Improving isoscapes and quantifying influence of landscape and in-stream processes on strontium isotopes in rivers. Geophys. Res. Lett. 43(10): 5043-5051. doi:10.1002/2016GL068904.

Bruslé, J., and Quignard, J.P. 2013. Biologie des poissons d'eau douce européens. Lavoisier, Paris.

Campana, S.E., and Thorrold, S.R. 2001. Otoliths, increments, and elements: keys to comprehensive understanding of fish populations? Can. J. Fish. Aquat. Sci. 58(1): 30-38. doi:10.1139/f00-177. 
629 Cassou-Leins, F., and Cassou-Leins, J.J. 1981. Recherches sur la biologie et 1'halieutique des migrateurs de la Garonne et principalement de 1'Alose, Alosa alosa L. M.Sc. thesis, Institut National Polytechnique, Toulouse.

Cassou-Leins, J.J., Cassou-Leins, F., Boisneau, P., and Baglinière, J.L. 2000. La reproduction. In Les aloses (Alosa alosa et Alosa fallax spp.). Écobiologie et variabilité des populations. Edited by J.L. Baglinière and P. Elie. INRA-CEMAGREF, Paris. pp. 73-92.

Castelnaud, G., Rochard, E., and Le Gat, Y. 2001. Analyse de la tendance de l'abondance de l'alose Alosa alosa en Gironde à partir de l'estimation d'indicateurs halieutiques sur la période 1977-1998. Bull. Fr. Pêche Piscic. 362/363: 989-1015. doi:10.1051/kmae:2001032.

Cellule Migrateurs Charente Seudre. 2017. Rapport des actions. EPTB Charente, Groupement des fédérations de pêche du Poitou-Charentes, CREAA. Programme d'actions 20162020 pour la sauvegarde et la restauration des poissons migrateurs amphihalins sur les bassins Charente et Seudre [online]. Available from http://oai.eau-adourgaronne.fr/oai-documents/61719/GED_00000000.pdf [accessed 6 November 2018].

Chang, M.Y., and Geffen, A.J. 2013. Taxonomic and geographic influences on fish otolith microchemistry. Fish. Fish. 14(4): 458-492. doi:10.1111/j.1467-2979.2012.00482.x.

Costoya, X., Fernández-Nóvoa, D., and Gómez-Gesteira, M. 2017. Loire and Gironde turbid plumes: Characterization and influence on thermohaline properties. J. Sea. Res. 130: 7-16. doi:10.1016/j.seares.2017.04.003. 
650 Daverat, F., Martin, J., Fablet, R., and Pécheyran, C. 2011. Colonisation tactics of three temperate catadromous species, eel Anguilla anguilla, mullet Liza ramada and flounder Plathychtys flesus, revealed by Bayesian multielemental otolith microchemistry approach. Ecol. Freshw. Fish. 20: 42-51. doi:10.1111/j.16000633.2010.00454.x.

De Groot, S.J. 2002. A review of the past and present status of anadromous fish species in the Netherlands: is restocking the Rhine feasible?. Hydrobiologia, 478: 205-218. doi:10.1023/A:1021038916271.

Denwood, M. 2013. runjags: an R package providing interface utilities, distributed computing methods and additional distributions for MCMC models in JAGS. J. Stat. Softw. 71(9): 1-25. doi:10.18637/jss.v071.i09.

Elie, P., Taverny, C., Mennesson-Boisneau, C., and Sabatié, M.R. 2000. L'exploitation halieutique. In Les aloses (Alosa alosa et Alosa fallax spp.). Écobiologie et variabilité des populations. Edited by J.L. Baglinière and P. Elie. CEMAGREF-INRA Editions, Paris. pp. 199-226.

Gao, Y., and Beamish, R.J. 2003. Stable isotope variations in otoliths of Pacific halibut (Hippoglossus stenolepis) and indications of the possible 1990 regime shift. Fish. Res. 60(2-3): 393-404. doi:10.1016/S0165-7836(02)00134-0.

Hamann, E.J., and Kennedy, B.P. 2012. Juvenile dispersal affects straying behaviors of adults in a migratory population. Ecology, 93(4): 733-740. doi:10.1890/11-1009.1.

Hasselman, D.J., Anderson, E.C., Argo, E.E., Bethoney, N.D., Gephard, S.R., Post, D.M., Schondelmeier, B.P., Schultz, T.F., Willis, T.V., and Palkovacs, E.P. 2015. Genetic 
stock composition of marine bycatch reveals disproportional impacts on depleted river herring genetic stocks. Can. J. Fish. Aquat. Sci. 73(6): 951-963. doi:10.1139/cjfas2015-0402.

Hobson, K.A. 1999. Tracing origins and migration of wildlife using stable isotopes: a review. Oecologia, 120(3): 314-326. doi:10.1007/s004420050865.

Hobson, K.A., Barnett-Johnson, R., and Cerling, T. 2010. Using isoscapes to track animal migration. In Isoscapes. Understanding Movement, Pattern, and Process on Earth Through Isotope Mapping. Edited by J.B. West, G.J. Bowen, T.E. Dawson and K.P. Tu. Springer, Dordrecht, pp. 273-298.

Huntsman, B.M., Falke, J.A., Savereide, J.W., and Bennett, K.E. 2017. The role of densitydependent and-independent processes in spawning habitat selection by salmon in an $\begin{array}{lllll}\text { Arctic } & \text { riverscape. }\end{array}$ doi:doi.org/10.1371/journal.pone.0177467.

ICES. 2015. Report of the Workshop on Lampreys and Shads (WKLS), 27-29 November 2014, Lisbon, Portugal. ICES CM 2014/SSGEF:13 [online]. Available from http://ices.dk/sites/pub/Publication\%20Reports/Expert\%20Group\%20Report/SSGEP D/2015/01\%20WKLS\%20\%20Report\%20of\%20the\%20Workshop\%20on\%20Lampr eys\%20and\%20Shads.pdf [accessed 6 November 2018].

Irigoien, X., Fernandes, J.A., Grosjean, P., Denis, K., Albaina, A., and Santos, M. 2008. Spring zooplankton distribution in the Bay of Biscay from 1998 to 2006 in relation with anchovy recruitment. J. Plankton. Res. 31(1): 1-17. doi:10.1093/plankt/fbn096. 
Jalón-Rojas, I., Schmidt, S., and Sottolichio, A. 2015. Turbidity in the fluvial Gironde Estuary (southwest France) based on 10-year continuous monitoring: sensitivity to hydrological conditions. Hydrol. Earth. Syst. Sc. 19(6): 2805-2819. doi:10.5194/hess19-2805-2015.

Johnson, R.C., Garza, J.C., MacFarlane, R.B., Grimes, C.B., Phillis, C.C., Koch, P.L., Weber, P.K., and Carr, M.H. 2016. Isotopes and genes reveal freshwater origins of Chinook salmon Oncorhynchus tshawytscha aggregations in California's coastal ocean. Mar. Ecol. Prog. Ser. 548: 181-196. doi:10.3354/meps11623.

Jolly, M.T., Aprahamian, M.W., Hawkins, S.J., Henderson, P.A., Hillman, R., O’Maoiléidigh, N., Maitland, P.S., Piper, R., and Genner, M.J. 2012. Population genetic structure of protected allis shad (Alosa alosa) and twaite shad (Alosa fallax). Mar. Biol. 159(3): 675-687. doi:10.1007/s00227-011-1845-x.

Keefer, M.L., and Caudill, C.C. 2014. Homing and straying by anadromous salmonids: Areview of mechanisms and rates. Rev. Fish. Biol. Fisher. 24(1): 333-368. doi:10.1007/s11160-013-9334-6.

Kennedy, B.P., Blum, J.D., Folt, C.L., and Nislow, K.H. 2000. Using natural strontium isotopic signatures as fish markers: methodology and application. Can. J. Fish. Aquat. Sci. 57(11): 2280-2292. doi:10.1139/f00-206.

Koutsikopoulos, C., and Le Cann, B. 1996. Physical processes and hydrological structures related to the Bay of Biscay anchovy. Sci. Mar. 60(2): 9-19. 
Laiz, I., Ferrer, L., Plomaritis, T.A., and Charria, G. 2014. Effect of river runoff on sea levelfrom in-situ measurements and numerical models in the Bay of Biscay. DeepSea. Res. Pt. II. 106: 49-67. doi:10.1016/j.dsr2.2013.12.013.

Lambert, P., Pronier, O., Rochard, E., and Martin-Vandembulcke, D. 1997. Analyse des données issues du suivi de la faune circulante aux abords de la centrale de Braud et Saint-Louis. Cas des juvéniles d'aloses (Alosa alosa), des crevettes blanches (Palaemon longirostris) et des civelles d'anguilles (Anguilla anguilla). Etude 28, Departement gestion des milieux aquatiques, Unité Ressources aquatiques continentales, Bordeaux.

La Mesa, G., Annunziatellis, A., Filidei Jr. E., and Fortuna, C.M. 2015. Modeling environmental, temporal and spatial effects on Twaite Shad (Alosa fallax) bycatches in the central Mediterranean Sea. Fish. Oceanogr. 24(2): 107-117. doi:10.1111/fog.12093.

Lassalle, G., Trancart, T., Lambert, P., and Rochard, E. 2008. Latitudinal variations in age and size at maturity among allis shad Alosa alosa populations. J. Fish Biol. 73(7): 1799-1809. doi:10.1111/j.1095-8649.2008.02036.x.

Legrand, M., and Besse, T. 2018. Paroles de migrateurs. Retour sur l'année 2017. Rapport $\mathrm{n}^{\circ} 16 \quad$ [online]. $\quad$ Available from $\mathrm{http} / / \mathrm{www}$.migrateursloire.fr/telechargement/documentation/paroles-de-migrateurs/Paroles-de-MigrateursN16.pdf [accessed 6 November 2018].

Le Pape, O., Chauvet, F., Mahévas, S., Lazure, P., Guérault, D., and Désaunay, Y. 2003. Quantitative description of habitat suitability for the juvenile common sole (Solea solea, L.) in the Bay of Biscay (France) and the contribution of different habitats to 
the adult population. J. Sea. Res. 50(2-3): 139-149. doi:10.1016/S13851101(03)00059-5.

Limburg, K.E., and Waldman, J.R. 2009. Dramatic Declines in North Atlantic Diadromous Fishes. BioScience, 59(11): 955-965. doi:10.1525/bio.2009.59.11.7.

Lochet, A. 2006. Dévalaison des juveniles et tactiques gagnantes chez la grande Alose Alosa alosa et 1'Alose feinte Alosa fallax: Apports de la microchimie et de la microstructure des otolithes. M.Sc. thesis, Université Bordeaux I, Bordeaux.

Loewen, T.N., Reist, J.D., Yang, P., Koleszar, A., Babaluk, J.A., Mochnacz, N., and Halden, N.M. 2015. Discrimination of northern form Dolly Varden Char (Salvelinus malma malma) stocks of the North Slope, Yukon and Northwest Territories, Canada via otolith trace elements and ${ }^{87} \mathrm{Sr} /{ }^{86} \mathrm{Sr}$ isotopes. Fish. Res. 170: 116-124. doi:10.1016/j.fishres.2015.05.025.

Lohmann, K.J., Putman, N.F., and Lohmann, C.M.F. 2008. Geomagnetic imprinting: a unifying hypothesis of long-distance and natal homing in salmon and sea turtles. P. Natl. Acad. Sci. USA. 105: 19096-19101. doi:10.1073/pnas.0801859105.

Martin, J., Bareille, G., Berail, S., Pécheyran, C., Gueraud, F., Lange, F., Daverat, F., Bru, N., Beall, E., Barracou, D., and Donard, O. 2013. Persistence of a southern Atlantic salmon population: Diversity of natal origins from otolith elemental and $\mathrm{Sr}$ isotopic signatures. Can. J. Fish. Aquat. Sci. 70(2): 182-197. doi:10.1139/cjfas-2012-0284.

Martin, J., Rougemont, Q., Drouineau, H., Launey, S., Jatteau, P., Bareille, G., Berail, S., Pécheyran, C., Feunteun, E., Roques, S., Clavé, D., Nachón, D.J., Antunes, C., Mota, M., Réveillac, E., and Daverat, F. 2015. Dispersal capacities of anadromous Allis shad 
population inferred from a coupled genetic and otolith approach. Can. J. Fish. Aquat. Sci. 72(7): 991-1003. doi:10.1139/cjfas-2014-0510.

Martin-Vandembulcke, D. 1999. Dynamique de population de la grande alose (Alosa alosa, L. 1758) dans le bassin versant Gironde-Garonne-Dordogne (France): analyse et prévision par modélisation. M.Sc. thesis, Toulouse: Ecole Nationale Polytechnique, Toulouse.

Mennesson-Boisneau, C. 1990. Migration, répartition, reproduction et caractéristiques biologiques des aloses (Alosa sp.) dans le bassin de la Loire. M.Sc. thesis, Universités de Rennes et de Paris Val de Marne, Paris.

Morais, P., and Daverat, F. 2016. An Introduction to Fish Migration. CRC Press, New York.

Motos, L., Uriarte, A., and Valencia, V. 1996. The spawning environment of the Bay of Biscay anchovy (Engraulis encrasicolus L.). Sci. Mar. 60(2): 237-255.

Munro, A.R., McMahon, T.E., and Ruzycki, J.R. 2005. Natural chemical markers identify source and date of introduction of an exotic species: lake trout (Salvelinus namaycush) in Yellowstone Lake. Can. J. Fish. Aquat. Sci. 62(1): 79-87. doi:10.1139/f04-174.

Nachón, D.J. 2017. Dinámica poblacional y microquímica de los otolitos de las poblaciones de saboga, Alosa fallax (Lacépède, 1803), de los ríos Ulla y Miño. M.Sc. thesis, Universidade de Santiago de Compostela, Santiago de Compostela.

Nachón, D.J., Mota, M., Antunes, C., Servia, M.J., and Cobo, F. 2016. Marine and continental distribution and dynamic of the early spawning migration of twaite shad (Alosa fallax (Lacépède, 1803)) and allis shad (Alosa alosa (Linnaeus, 1758)) in the 
north-west of the Iberian Peninsula. Mar. Freshwater. Res. 67(8): 1229-1240. doi:10.1071/MF14243.

Perrier, C., Evanno, G., Belliard, J., Guyomard, R., and Baglinière, J.L. 2009. Natural recolonization of the Seine River by Atlantic salmon (Salmo salar) of multiple origins. Can. J. Fish. Aquat. Sci. 67(1): 1-4. doi:10.1139/F09-190.

Plummer, M. 2003. JAGS: A program for analysis of Bayesian graphical models using Gibbs sampling. In Proceedings of the $3^{\text {rd }}$ International Workshop on Distributed Statistical Computing (DSC 2003), Vienna , 20-22 March 2003. Kurt Hornik, Friedrich Leisch and Achim Zeileis. pp. 1-10.

Pouilly, M., Point, D., Sondag, F., Henry, M., and Santos, R.V. 2014. Geographical origin of Amazonian freshwater fishes fingerprinted by ${ }^{87} \mathrm{Sr} r{ }^{86} \mathrm{Sr}$ ratios on fish otoliths and scales. Environ. Sci. Technol. 48(16): 8980-8987. doi:10.1021/es500071w.

Prouzet, P., Martinet, J.P., and Badia, J. 1994. Caractérisation biologique et variation des captures de la grande alose (Alosa alosa) par unité d'effort sur le fleuve Adour (Pyrénées Atlantiques, France). Aquat. Living. Resour. 7(1): 1-10. doi:10.1051/alr:1994001.

Putman, N.F., Lohmann, K.J., Putman, E.M., Quinn, T.P., Klimley, A.P., and Noakes, D.L. 2013. Evidence for geomagnetic imprinting as a homing mechanism in Pacific salmon. Curr. Biol. 23(4): 312-316. doi:10.1016/j.cub.2012.12.041.

Randon, M., Daverat, F., Bareille, G., Jatteau, P., Martin, J., Pécheyran, C., and Drouineau, H. 2018. Quantifying exchanges of Allis shads between river catchments by 
combining otolith microchemistry and abundance indices in a Bayesian model. ICES. J. Mar. Sci. 75: 9-21. doi:10.1093/icesjms/fsx 148.

Rougier, T., Drouineau, H., Dumoulin, N., Faure, T., Deffuant, G., Rochard, E., and Lambert, P. 2014. The GR3D model, a tool to explore the Global Repositioning Dynamics of Diadromous fish Distribution. Ecol. Model. 283: 31-44. doi:10.1016/j.ecolmodel.2014.03.019.

Rougier, T., Lambert, P., Drouineau, H., Girardin, M., Castelnaud, G., Carry, L., Aprahamian, M.W., Rivot, E., and Rochard, E. 2012. Collapse of allis shad, Alosa alosa, in the Gironde system (southwest France): environmental change, fishing mortality, or Allee effect?. ICES. J. Mar. Sci. 69(10): 1802-1811. doi:10.1093/icesjms/fss149.

Sabatié, M.R. 1993. Recherches sur l'écologie et la biologie des aloses au Maroc (Alosa alosa Linné, 1758 et Alosa fallax Lacépède, 1803): exploitation et taxonomie des populations atlantiques, bioécologie des aloses de l'oued Sebou. M.Sc. thesis, Université de Bregtane Occidentale, Brest.

Schmidt, S., Etcheber, H., Sottolichio, A., and Castaing, P. 2016. Le réseau MAGEST: bilan de 10 ans de suivi haute-fréquence de la qualité des eaux de l'estuaire de la Gironde $\begin{array}{llll}\text { [online]. } & \text { Available } & \text { from } & \text { http://www.magest.u- }\end{array}$ bordeaux1.fr/files/docs/PublicationHFMAREL2014-SchmidtS.pdf $\quad$ [accessed 27 February 2019].

Taverny, C. 1991. Contribution à la connaissance de la dynamique des populations d'aloses (Alosa alosa L. et Alosa fallax Lacépède), dans le système fluvio-estuarien de la 

Gironde: pêche, biologie et écologie. Étude particulière de la dévalaison et de l'impact des activités humaines. M.Sc. thesis, Université de Bordeaux 1, Bordeaux.

Taverny, C., and Elie, P. 2001. Répartition spatio-temporelle de la grande alose Alosa alosa (Linné, 1766) et de l'alose feinte Alosa fallax (Lacépède, 1803) dans le Golfe de Gascogne. Bull. Fr. Pêche. Piscic. 362/363: 803-821. doi:10.1051/kmae:2001020.

Taverny, C., Belaud, A., Elie, P., and Sabatié, M.R. 2000b. Influence des activités humaines. In Les aloses (Alosa alosa et Alosa fallax spp.). Écobiologie et variabilité des populations. Edited by J.L. Baglinière and P. Elie. INRA-CEMAGREF, Paris. pp. $227-248$.

Taverny, C., Cassou-Leins, J.J., Cassou-Leins, F., and Elie, P. 2000a. De l'oeuf à l'adulte en mer. In Les aloses (Alosa alosa et Alosa fallax spp.). Écobiologie et variabilité des populations. Edited by J.L. Baglinière and P. Elie. INRA-CEMAGREF, Paris. pp. 93124.

Trancart, T., Rochette, S., Acou, A., Lasne, E., and Feunteun, E. 2014. Modeling marine shad distribution using data from French bycatch fishery surveys. Mar. Ecol. Prog. Ser. 511: 181-192. doi:10.3354/meps 10907.

Turner, S.M., Limburg, K.E., and Palkovacs, E.P. 2015. Can different combinations of natural tags identify river herring natal origin at different levels of stock structure? Can. J. Fish. Aquat. Sci. 72(6): 845-854. doi:10.1139/cjfas-2014-0403.

Walther, B.D., and Limburg, K.E. 2012. The use of otolith chemistry to characterize diadromous migrations. J. Fish. Biol. 81(2): 796-825. doi:10.1111/j.10958649.2012.03371.x. 
Walther, B.D., and Thorrold, S.R. 2006. Water, not food, contributes the majority of strontium and barium deposited in the otoliths of a marine fish. Mar. Ecol. Prog. Ser. 311: 125-130. doi:10.3354/meps311125.

Walther, B.D., and Thorrold, S.R. 2008. Continental-scale variation in otolith geochemistry of juvenile American shad (Alosa sapidissima). Can. J. Fish. Aquat. Sci. 65: 26232635. doi:10.1139/F08-164.

Walther, B.D., and Thorrold, S.R. 2010. Limited diversity in natal origins of immature anadromous fish during ocean residency. Can. J. Fish. Aquat. Sci. 67(10): 1699-1707. doi:10.1139/F10-086.

Walther, B.D., Thorrold, S.R., and Olney, J.E. 2008. Geochemical signatures in otoliths record natal origins of American Shad. Trans. Am. Fish. Soc. 137: 57-69. doi:10.1577/T07-029.1.

Willmes, M., Bataille, C.P., James, H.F., Moffat, I., McMorrow, L., Kinsley, L., Amstrong, R.A., Eggins, S., and Grün, R. 2018. Mapping of bioavailable strontium isotope ratios in France for archaeological provenance studies. Appl. Geochem. 90: 75-86. doi:10.1016/j.apgeochem.2017.12.025.

Zimmerman, C.E., Swanson, H.K., Volk, E.C., and Kent, A.J. 2013. Species and life history affect the utility of otolith chemical composition for determining natal stream of origin for Pacific salmon. Trans. Am. Fish. Soc. 142(5): 1370-1380. doi:10.1080/00028487.2013.811102. 


\section{Table captions}

867 Table 1. Total canonical structure coefficients for canonical discriminant analysis performed

868 on elemental and Sr isotopic ratios in water samples. Taken from Martin et al. (2015). 
Fig. 1. Sampling surveys campaigns and collection locations of the Allis shad and Twaite shad subadults retained for this study. Marine catches were grouped into two marine regions, Bay of Biscay North (BBN) and Bay of Biscay Center (BBC). The French rivers where water and Allis shad otoliths samples were collected to build the Bayesian model of attribution to the river of origin, as described in Randon et al. (2018), are also shown. Only the lowermost sections of the main rivers are showed.

Fig. 2. Confusion matrix of reallocation between rivers. If the correlation is positive there is confusion while if the correlation is negative it means that there is a good discrimination between rivers. Colours (or shades of grey) as well as the size of the circles provide information about the intensity and direction of the correlations. Only significant correlations $(p$-value $<0.05)$ are shown.

Fig. 3. Summary of all reallocation probabilities for each river separated by species and marine region. Rivers were ordered from north to south. Each boxplot represent the first quantile $(25 \%)$, the median $(50 \%)$ and the last quantile $(75 \%)$ of the distribution. The segments are the $95 \%$ credibility intervals.

Fig. 4. Most probable natal river assignations for Allis shad subadults. The map shows all potential sources and those that have contributed individuals to mixtures of subadults Allis shad are color-coded for the identification of the natal origin of individuals.

Fig. 5. Most probable natal river assignations for Twaite shad subadults. The map shows all potential sources and those that have contributed individuals to mixtures of subadults Twaite shad are color-coded for the identification of the natal origin of individuals. 
892 Fig. 6. Canonical discriminant plot of isotope $\left({ }^{87} \mathrm{Sr}:{ }^{86} \mathrm{Sr}\right)$ and elemental (Sr:Ca and Ba:Ca) 893 signatures from water samples collected from 17 rivers in 2013. Symbols represent water 894 samples, and ellipses are 95\% confidence intervals around each group. Grid scale is given $(d$ $895=1)$. Taken from Martin et al. (2015).

896 


\section{Tables}

898 Table 1. Total canonical structure coefficients for canonical discriminant analysis performed

899 on elemental and Sr isotopic ratios in water samples. Taken from Martin et al. (2015).

\begin{tabular}{rcc}
\hline \multicolumn{1}{l}{ Ratios } & CV1 & CV2 \\
\hline${ }^{87} \mathrm{Sr}:{ }^{86} \mathrm{Sr}$ & -0.880 & 0.362 \\
$\mathrm{Sr}: \mathrm{Ca}$ & 0.151 & -0.518 \\
$\mathrm{Ba}: \mathrm{Ca}$ & 0.034 & -0.205 \\
\hline
\end{tabular}




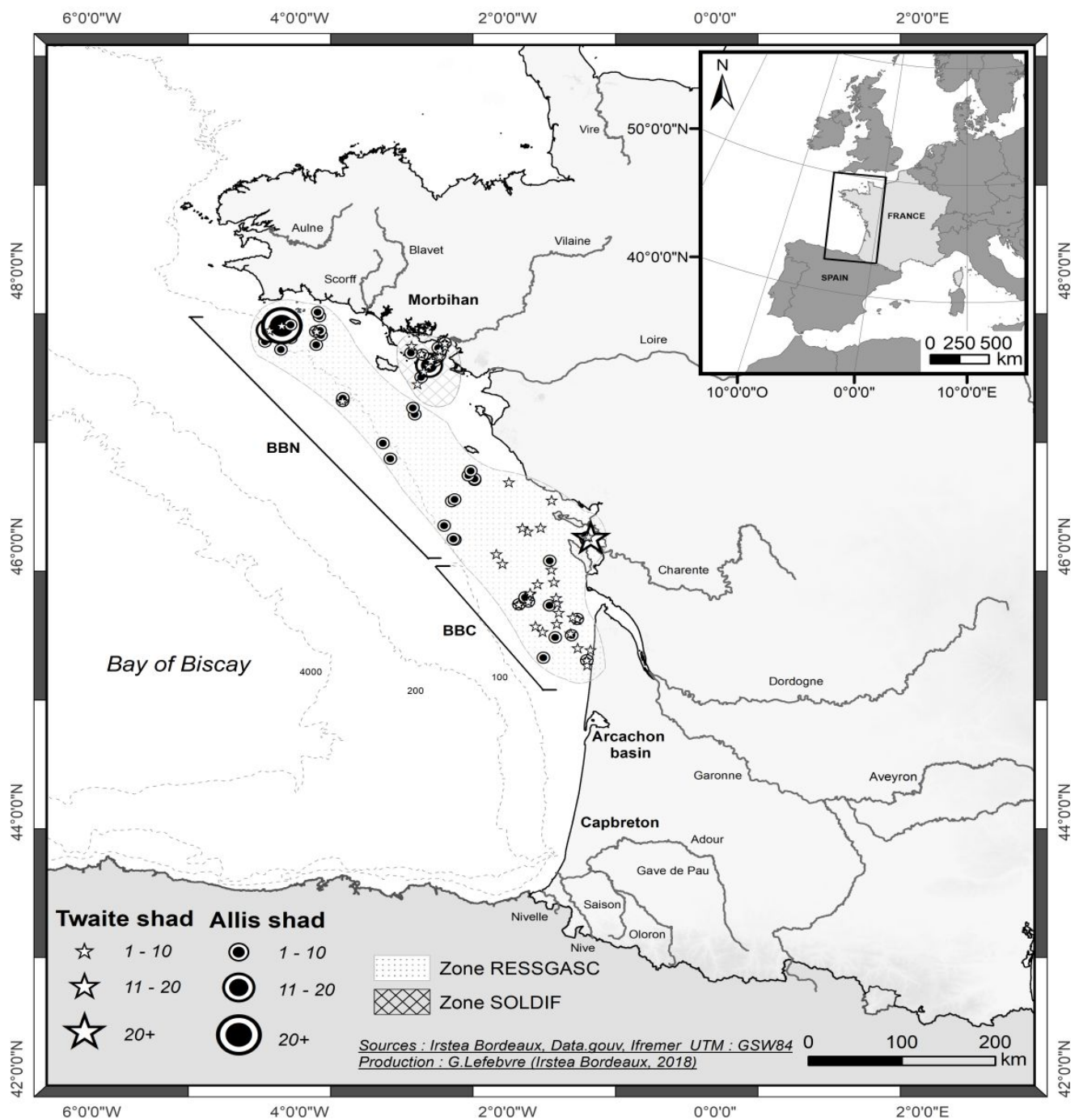

903 Fig.1. Sampling surveys campaigns and collection locations of the Allis shad and Twaite 904 shad subadults retained for this study. Marine catches were grouped into two marine regions, 905 Bay of Biscay North (BBN) and Bay of Biscay Center (BBC). The French rivers where water and Allis shad otoliths samples were collected to build the Bayesian model of attribution to the river of origin, as described in Randon et al. (2018), are also shown. Only the lowermost sections of the main rivers are showed. 


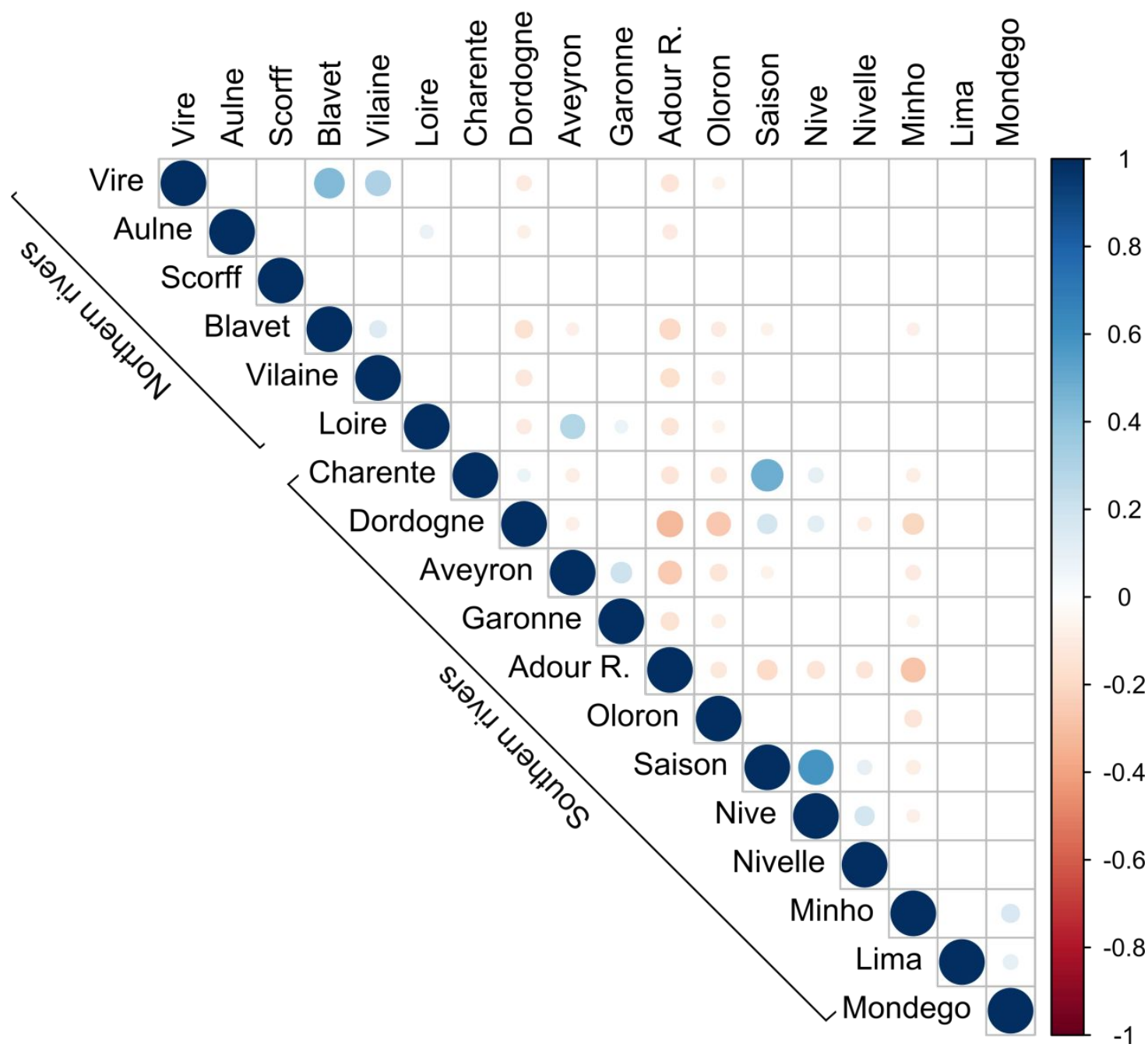

910 Fig.2. Confusion matrix of reallocation between rivers. Rivers were ordered from north to

911 south. If the correlation is positive there is confusion while if the correlation is negative it

912 means that there is a good discrimination between rivers. Colours (or shades of grey) as well

913 as the size of the circles provide information about the intensity and direction of the

914 correlations. Only significant correlations (p-value $<0.05)$ are shown. 


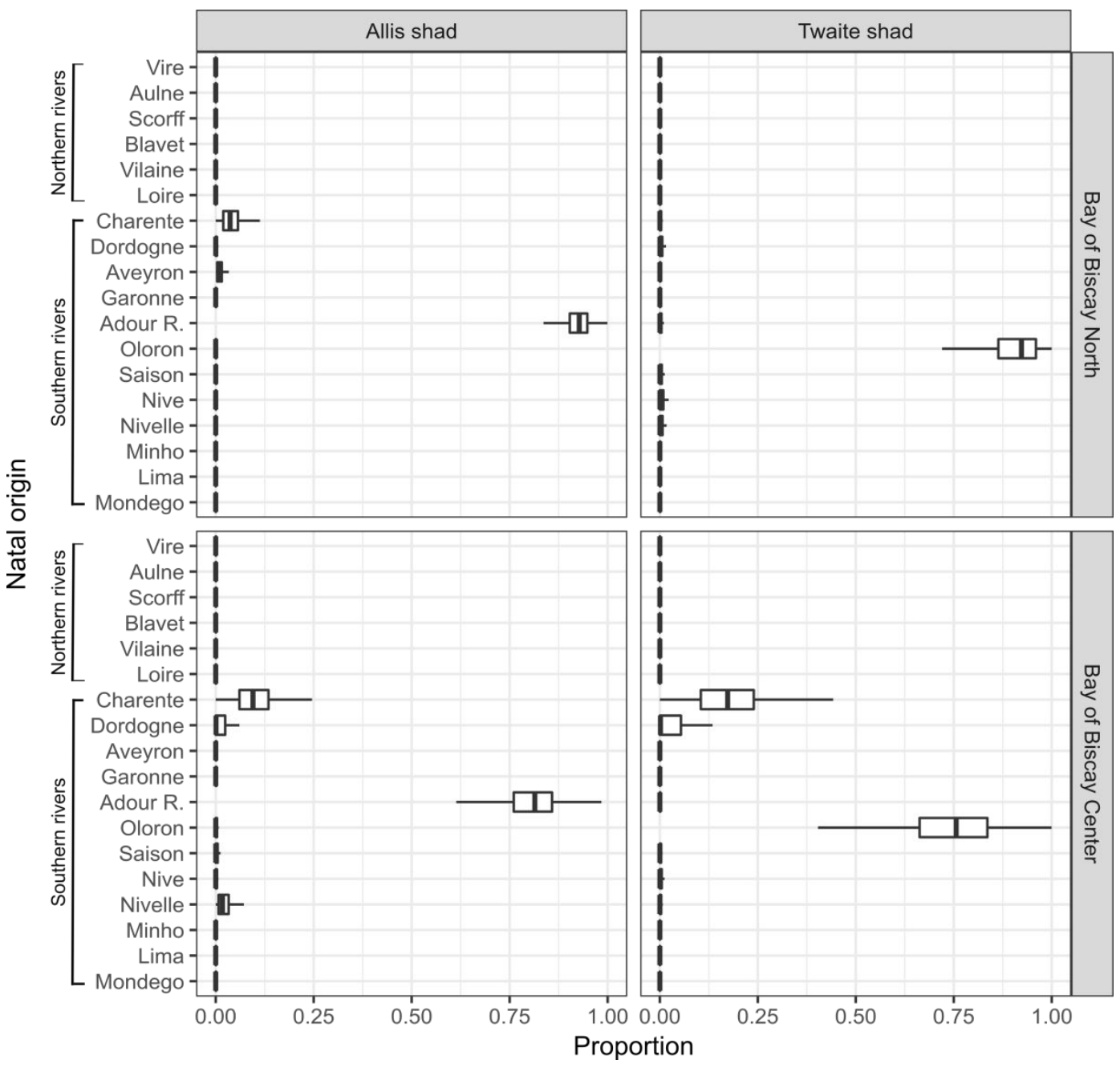

916 Fig.3. Summary of all reallocation probabilities for each river separated by species and 917 marine region. Rivers were ordered from north to south. Each boxplot represent the first quantile $(25 \%)$, the median $(50 \%)$ and the last quantile $(75 \%)$ of the distribution. The segments are the $95 \%$ credibility intervals. 


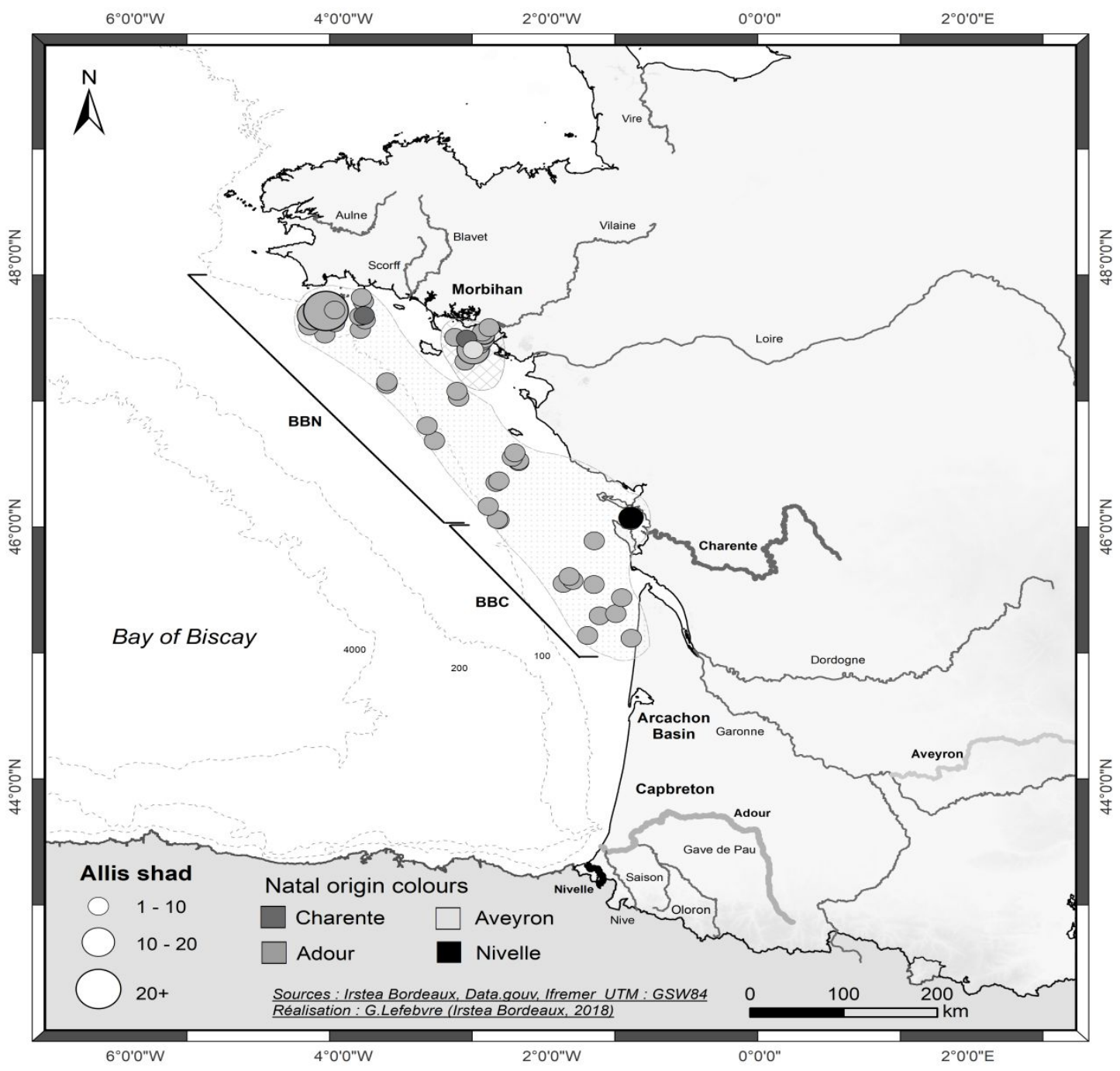

921 Fig.4. Most probable natal river assignations for Allis shad subadults. The map shows all potential sources and those that have contributed individuals to mixtures of subadults Allis shad are color-coded for the identification of the natal origin of individuals. 


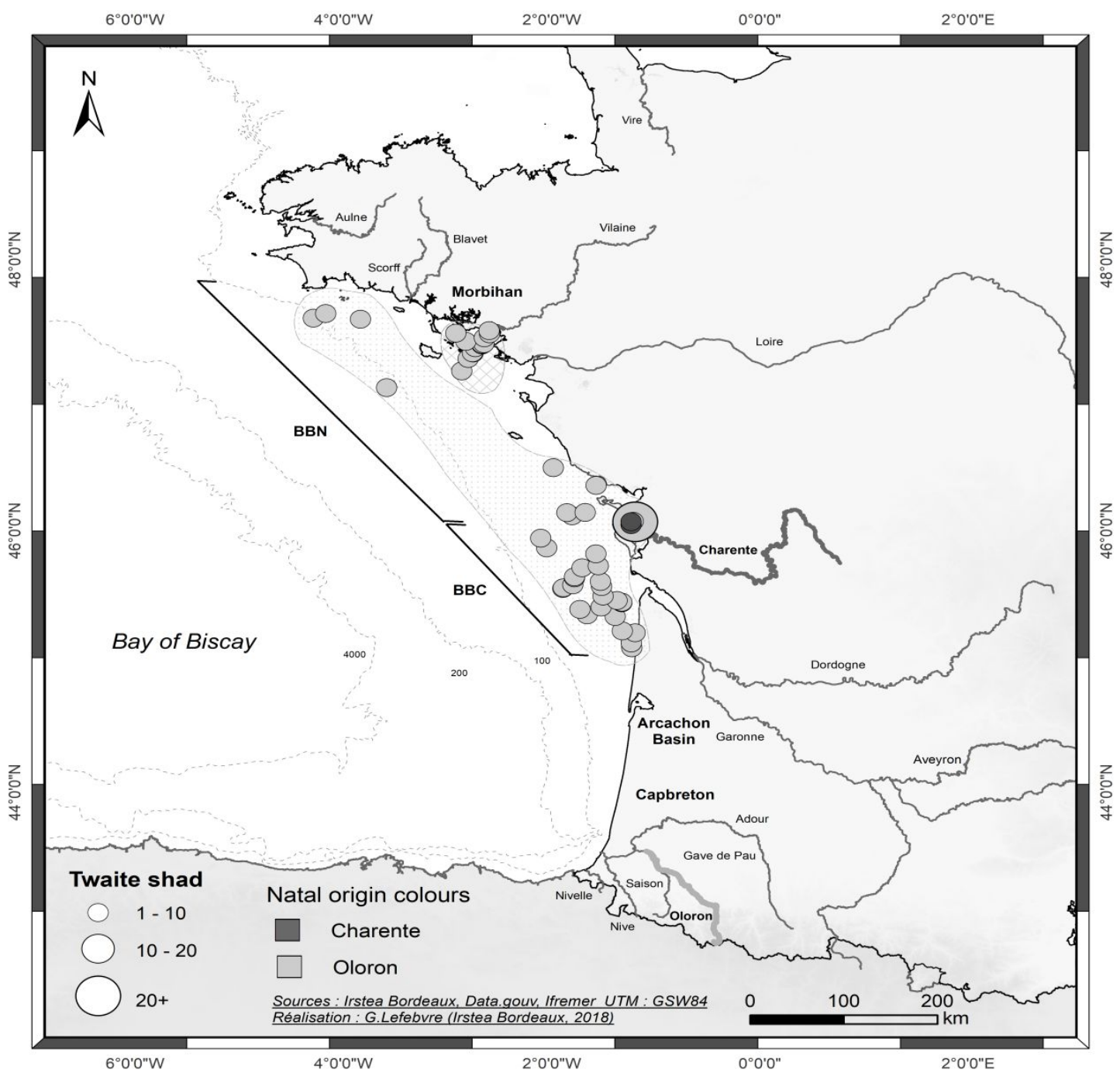

925 Fig.5. Most probable natal river assignations for Twaite shad subadults. The map shows all

926 potential sources and those that have contributed individuals to mixtures of subadults Twaite 927 shad are color-coded for the identification of the natal origin of individuals. 


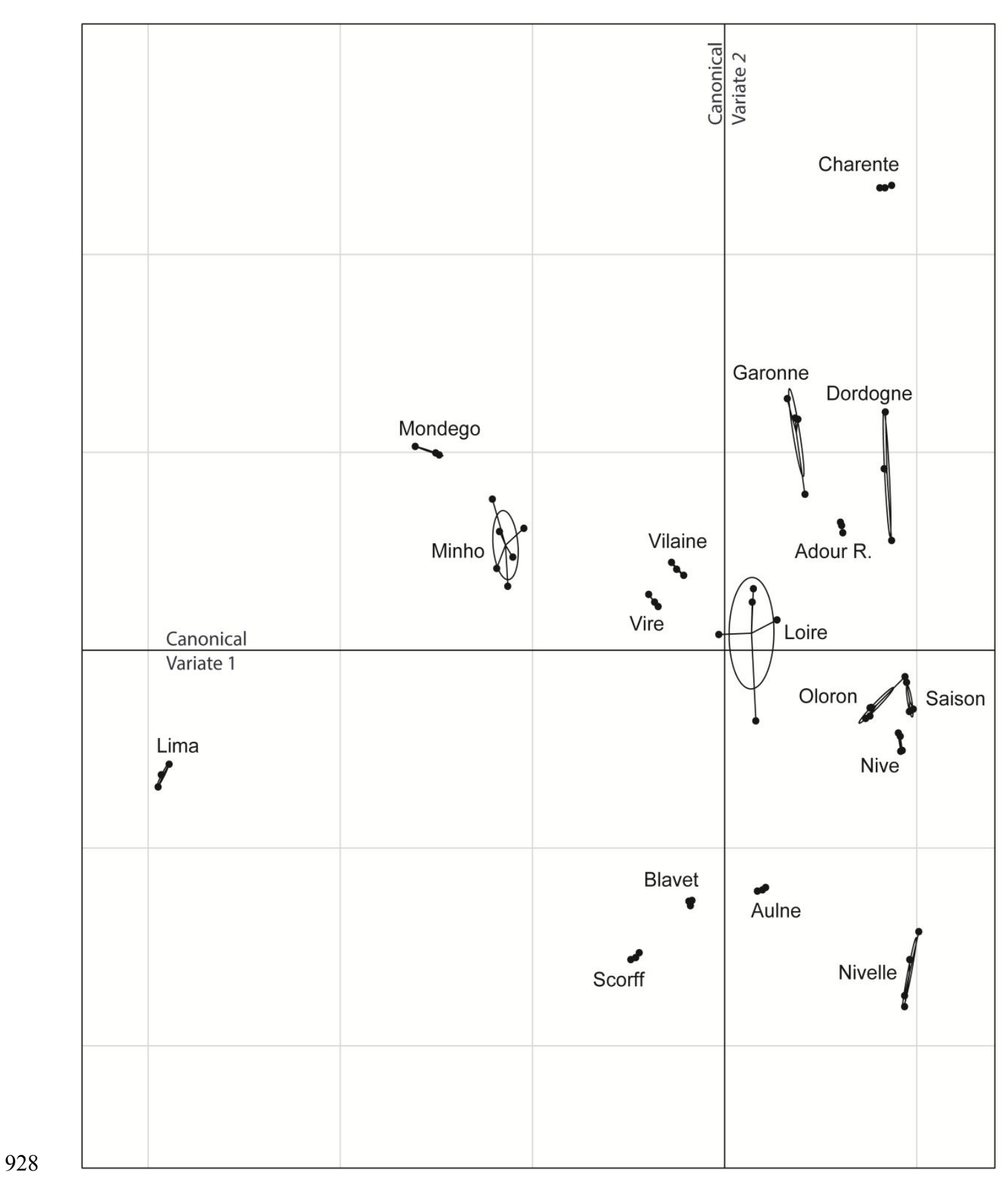

929 Fig. 6. Canonical discriminant plot of isotope $\left({ }^{87} \mathrm{Sr}:{ }^{86} \mathrm{Sr}\right)$ and elemental ( $\mathrm{Sr}: \mathrm{Ca}$ and $\left.\mathrm{Ba}: \mathrm{Ca}\right)$ 930 signatures from water samples collected from 17 rivers in 2013. Symbols represent water 931 samples, and ellipses are 95\% confidence intervals around each group. Grid scale is given $(d$ $932=1)$. Taken from Martin et al. (2015). 
Table 1. Total canocical structure coefficients for canonical discriminant analysis performed on elemental and Sr isotopic ratios in water samples. Taken from Martin et al. (2015).

\begin{tabular}{lcc}
\hline Ratios & CV1 & CV2 \\
\hline${ }^{87} \mathrm{Sr}:{ }^{86} \mathrm{Sr}$ & -0.88 & 0.362 \\
$\mathrm{Sr}: \mathrm{Ca}$ & 0.151 & -0.518 \\
$\mathrm{Ba}: \mathrm{Ca}$ & 0.034 & -0.205 \\
\hline
\end{tabular}




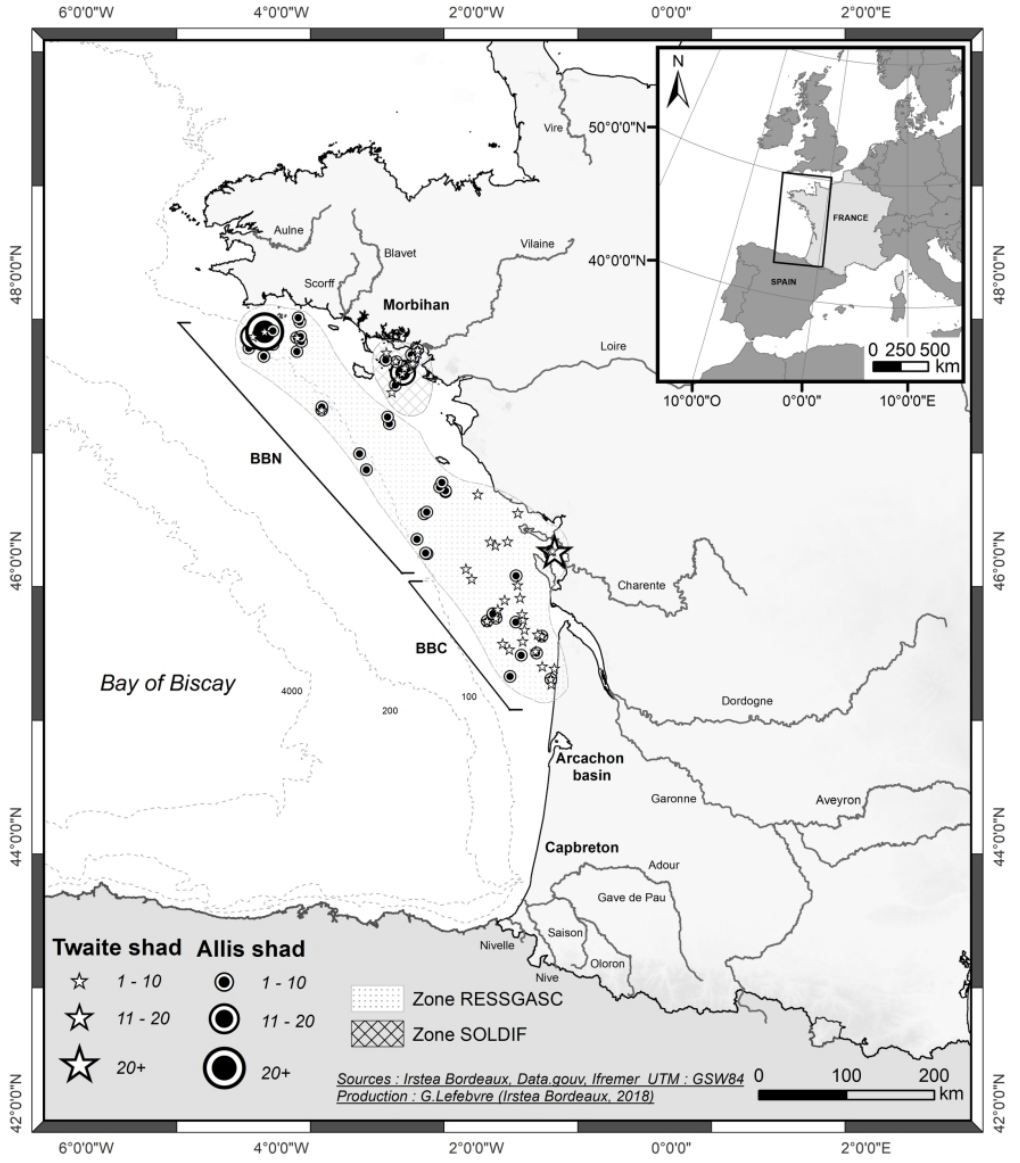

Fig. 1. Sampling surveys campaigns and collection locations of the Allis shad and Twaite shad subadults retained for this study. Marine catches were grouped into two marine regions, Bay of Biscay North (BBN) and Bay of Biscay Center (BBC). The French rivers where water and Allis shad otoliths samples were collected to build the Bayesian model of attribution to the river of origin, as described in Randon et al. (2018), are also shown. Only the lowermost sections of the main rivers are showed.

$210 \times 297 \mathrm{~mm}(300 \times 300$ DPI $)$ 
Page 53 of 56

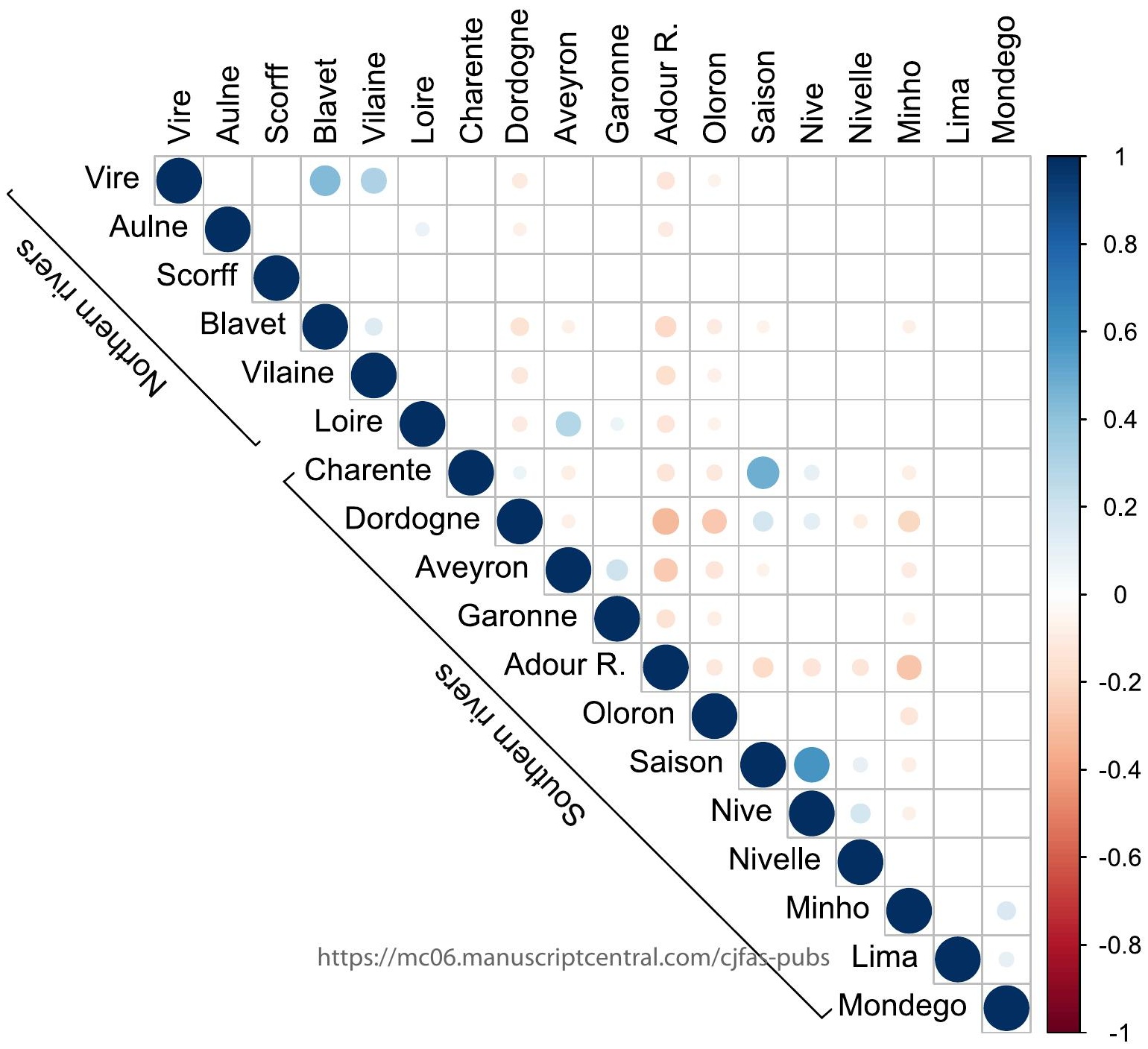




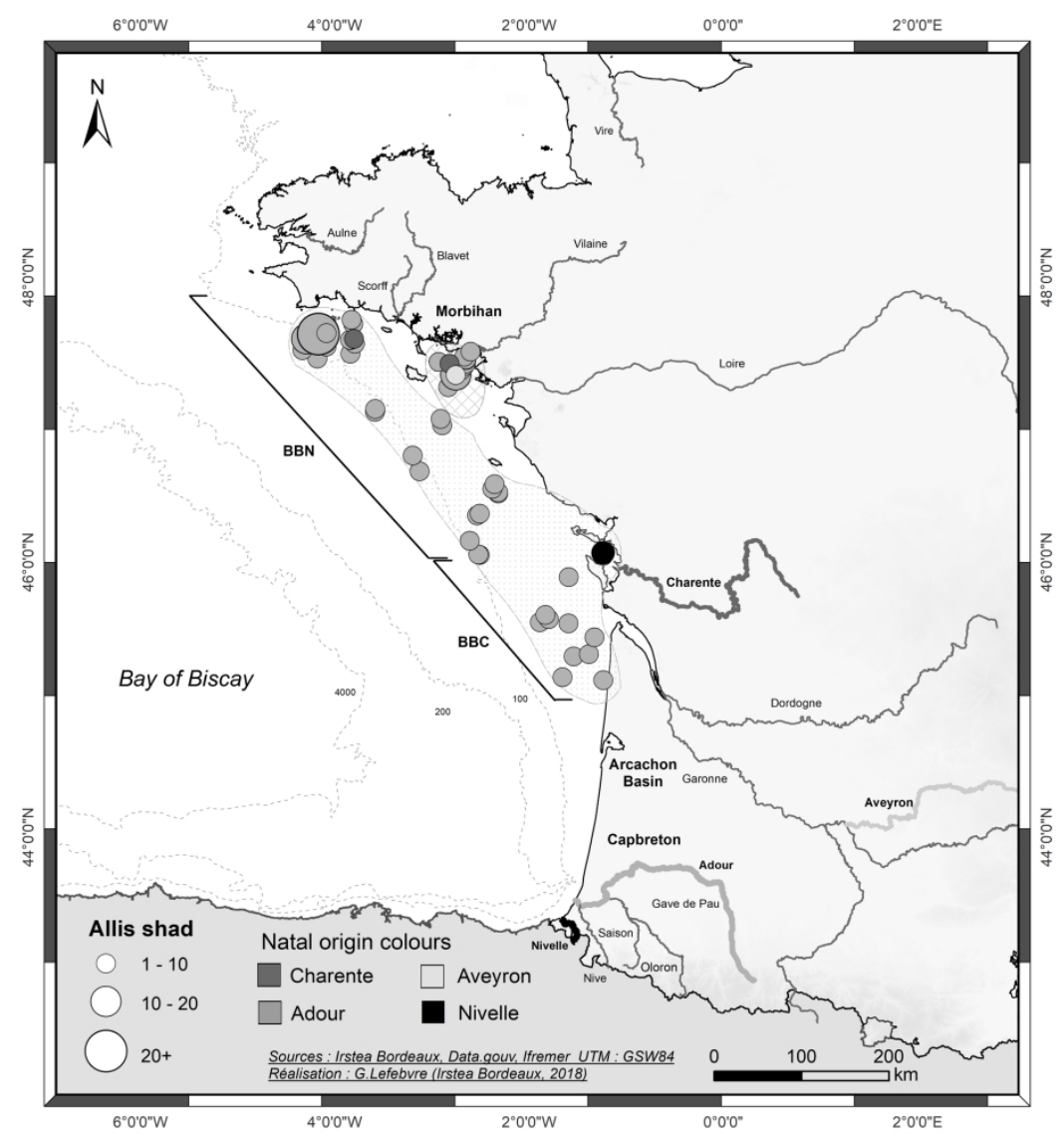

Fig. 4. Most probable natal river assignations for Allis shad subadults. The map shows all potential sources and those that have contributed individuals to mixtures of subadults Allis shad are color-coded for the identification of the natal origin of individuals.

$210 \times 297 \mathrm{~mm}(300 \times 300 \mathrm{DPI})$ 


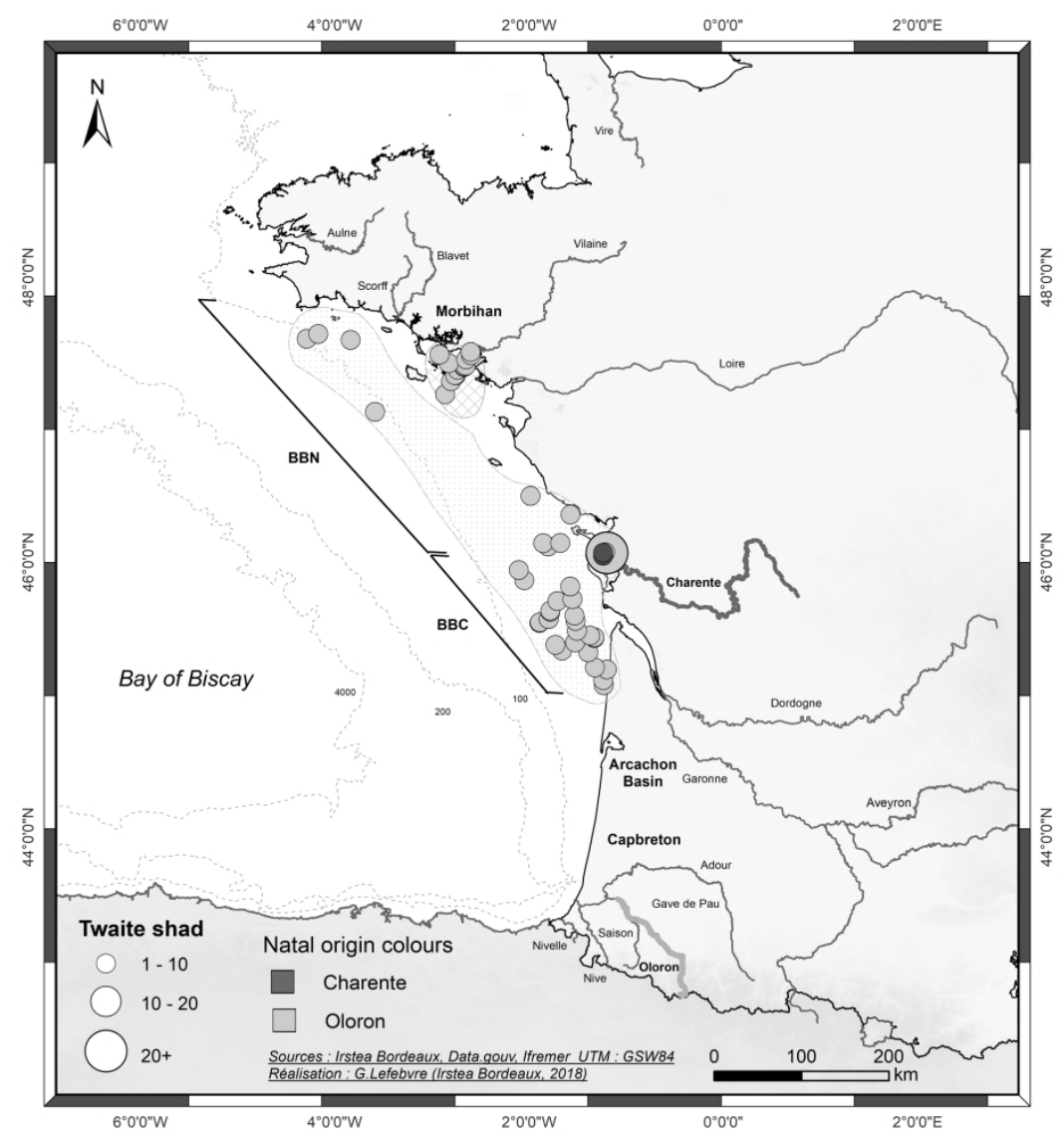

Fig. 5. Most probable natal river assignations for Twaite shad subadults. The map shows all potential sources and those that have contributed individuals to mixtures of subadults Twaite shad are color-coded for the identification of the natal origin of individuals.

$210 \times 297 \mathrm{~mm}(300 \times 300 \mathrm{DPI})$ 


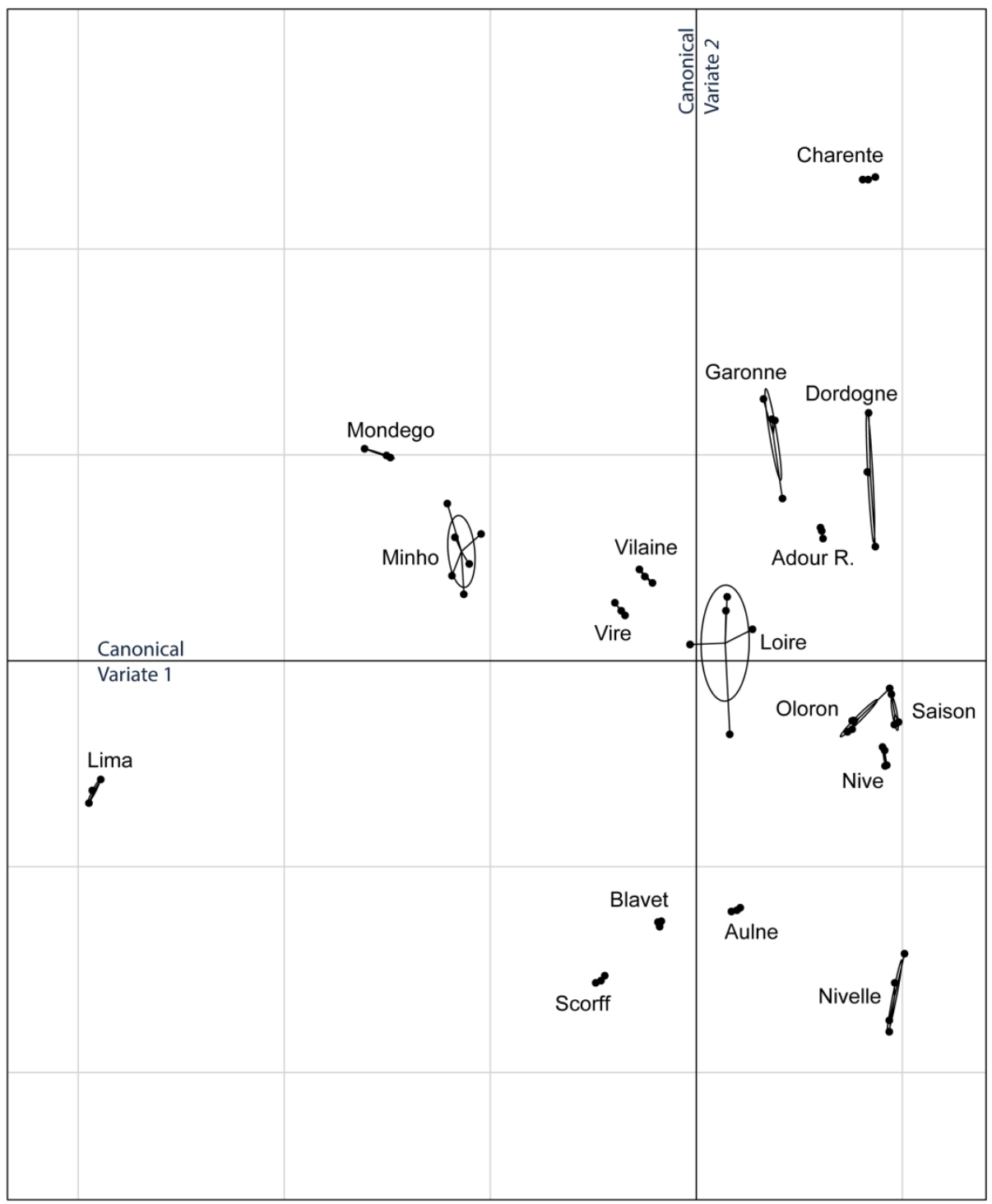

Fig. 6. Canonical discriminant plot of isotope (87Sr:86Sr) and elemental ( $\mathrm{Sr}: \mathrm{Ca}$ and $\mathrm{Ba}: \mathrm{Ca}$ ) signatures from water samples collected from 17 rivers in 2013. Symbols represent water samples, and ellipses are $95 \%$ confidence intervals around each group. Grid scale is given $(d=1)$. Taken from Martin et al. (2015).

$214 \times 239 \mathrm{~mm}(300 \times 300 \mathrm{DPI})$ 